\title{
On the origin of Acochlidia and other enigmatic euthyneuran gastropods, with implications for the systematics of Heterobranchia
}

\author{
Katharina M Jörger ${ }^{1 *}$, Isabella Stöger ${ }^{1}$, Yasunori Kano ${ }^{2}$, Hiroshi Fukuda ${ }^{3}$, Thomas Knebelsberger $^{1}$, Michael Schrödl ${ }^{1}$
}

\begin{abstract}
Background: A robust phylogenetic hypothesis of euthyneuran gastropods, as a basis to reconstructing their evolutionary history, is still hindered by several groups of aberrant, more or less worm-like slugs with unclear phylogenetic relationships. As a traditional "order" in the Opisthobranchia, the Acochlidia have a long history of controversial placements, among others influenced by convergent adaptation to the mainly meiofaunal habitats. The present study includes six out of seven acochlidian families in a comprehensive euthyneuran taxon sampling with special focus on minute, aberrant slugs. Since there is no fossil record of tiny, shell-less gastropods, a molecular clock was used to estimate divergence times within Euthyneura.

Results: Our multi-locus molecular study confirms Acochlidia in a pulmonate relationship, as sister to Eupulmonata. Previous hypotheses of opisthobranch relations, or of a common origin with other meiofaunal Euthyneura, are clearly rejected. The enigmatic amphibious and insectivorous Aitengidae incerta sedis clusters within Acochlidia, as sister to meiofaunal and brackish Pseudunelidae and limnic Acochlidiidae. Euthyneura, Opisthobranchia and Pulmonata as traditionally defined are non-monophyletic. A relaxed molecular clock approach indicates a late Palaeozoic diversification of Euthyneura and a Mesozoic origin of the major euthyneuran diversity, including Acochlidia.

Conclusions: The present study shows that the inclusion of small, enigmatic groups is necessary to solve deeplevel phylogenetic relationships, and underlines that "pulmonate" and "opisthobranch" phylogeny, respectively, cannot be solved independently from each other. Our phylogenetic hypothesis requires reinvestigation of the traditional classification of Euthyneura: morphological synapomorphies of the traditionally defined Pulmonata and Opisthobranchia are evaluated in light of the presented phylogeny, and a redefinition of major groups is proposed. It is demonstrated that the invasion of the meiofaunal habitat has occurred several times independently in various euthyneuran taxa, leading to convergent adaptations previously misinterpreted as synapomorphies. The inclusion of Acochlidia extends the structural and biological diversity in pulmonates, presenting a remarkable flexibility concerning habitat choice.
\end{abstract}

\section{Background}

Since the introduction of the Heterobranchia concept by Haszprunar [1,2], considerable advances have been achieved, solving the phylogeny of certain heterobranch groups (i.e. "families" or "orders") on morphological (e.g. Mikkelsen [3] on Cephalaspidea; Jensen [4] on Sacoglossa; Wägele and Willan [5] on Nudibranchia,

\footnotetext{
* Correspondence: Katharina.Joerger@zsm.mwn.de

'Bavarian State Collection of Zoology, Münchhausenstr. 21, 81247 München, Germany

Full list of author information is available at the end of the article
}

Klussmann-Kolb [6] on Aplysiidae) and molecular levels (e.g. Wollscheid-Lengeling et al. [7] on Nudibranchia; Wade et al. [8] on Stylommatophora; Klussmann-Kolb and Dinapoli [9] on Pteropoda). Members of the Euthyneura - the major heterobranch clade - have conquered marine, limnic and terrestrial habitats from the deep sea to the high mountains. As a result they form one of the most successful and diverse groups within Gastropoda, and even within Mollusca as regards species numbers and ecological diversity. Quite some effort has been dedicated to revealing relationships in the taxon, and to
C Biomed Central

() 2010 Jörger et al; licensee BioMed Central Ltd. This is an Open Access article distributed under the terms of the Creative Commons Attribution License (http://creativecommons.org/licenses/by/2.0), which permits unrestricted use, distribution, and reproduction in any medium, provided the original work is properly cited. 
supporting or rejecting the respective monophyly of traditional higher groupings such as Pulmonata and Opisthobranchia. Nevertheless, the phylogeny of the Euthyneura has remained partially unresolved and heavily discussed [see e.g. [10-17]]. While morphological analyses face the problem of convergent developments that might mask the true phylogenetic signal, and depend on the coding procedure for morphological characters [18], single-marker molecular analyses are challenged in choosing a suitable marker, and multi-locus molecular studies stand and fall with the available taxon sampling.

One major problem in molecular studies is that highly aberrant or derived taxa of uncertain taxonomic relationships "jump around" in phylogenetic analyses and weaken the phylogenetic signal for higher taxa. Members of such groups are often hard to obtain (especially for molecular purposes); thus, the groups are frequently either excluded from phylogenetic analyses or only included with a low number of representatives, resulting in poor overall taxon sampling. One attempt to support future phylogenetic approaches on a higher taxonomic level (i.e. Heterobranchia or Gastropoda) is to provide data on small enigmatic groups and their phylogenetic relationships step by step.

The Acochlidia, a traditional "order" of the Opisthobranchia since their establishment by Odhner [[19]; as Acochlidiacea], form one of the unsolved mysteries within Euthyneura [18]. Being a small group with only 28 valid species worldwide, these slugs are morphologically and biologically highly aberrant and diverse, comprising a series of unusual characters (e.g. secondary gonochorism, lack of copulatory organs, asymmetric radulae) [see e.g. [20-23]]. Most acochlidians live interstitially in marine sands, while some have conquered limnic systems (uniquely within opisthobranch gastropods). Their monophyly is widely accepted [20,22,24,25] especially since a proposed sister group relationship of the acochlidian family Ganitidae with Sacoglossa (based on the dagger-shaped radula teeth, see [26]) could be rejected based on a comprehensive parsimony analysis of morphological characters [22]. During the last years a series of studies have redescribed key acochlidian taxa in great detail, including 3D reconstructions [27-32], and added considerably to the morphological and biological knowledge of this previously little understood group. A first comprehensive cladistic analysis of their phylogeny is now established [22], but the identity of their sister group remains uncertain. Most recent morphological analyses suggested a common origin with either the equally enigmatic Rhodopemorpha [10], the diaphanid cephalaspidean Toledonia [25], or with runcinid or philinoid cephalaspideans $[22,33]$. However, morphology-based analyses by Schrödl and Neusser [22], demonstrated that Acochlidia usually group with other mesopsammic taxa, if any were included (i.e. with the sacoglossan Platyhedyle, the rhodopemorph Rhodope or the cephalaspideans Philinoglossa or Philine exigua). Thus, it is likely that convergent adaptations to the interstitial habitat mask the truly phylogenetic signals. Molecular markers independent from direct ecological pressures suggested an unresolved basal opisthobranch origin for Acochlidia ([34] based on nuclear $18 \mathrm{~S}$ rRNA and $28 \mathrm{~S}$ rRNA). A first combined multi-gene dataset led to the surprising result of Acochlidia clustering in a pulmonate relationship, united in a clade with Pyramidelloidea, Amphiboloidea and Eupulmonata [17]. However, only three derived acochlids [see [22]] were included, with partially missing data. Therefore this unexpected result requires re-examination based on complete multi-locus data and a more focused taxon sampling, including all previously suggested potential sister groups of Acochlidia. Most recently, another curiosity with potential affinities to Acochlidia has been described: the amphibious and insectivorous sea slug Aiteng ater from mangrove mud in Thailand [35]. Due to its unusual combination of morphological characters (prepharyngeal nerve ring, presence of ascus, uniseriate radula) it was placed in a new family, Aitengidae, with unclear phylogenetic relationships and affinities to Sacoglossa, Acochlidia and Cephalaspidea. A similar but still undescribed species was found in Japan, which was available for the present study. Morphologically it clearly belongs to the Aitengidae, but shows differences to $A$. ater at genus or species level (own unpublished data). Its affinity to $A$. ater is confirmed by comparison of the mitochondrial $16 \mathrm{~S}$ rRNAsequences (K. Händeler, pers. comm.).

The present study aims to clarify the origins and phylogenetic relationships of Acochlidia and potentially related enigmatic taxa such as Aitengidae, based on a combined molecular dataset from nuclear and mitochondrial markers. For the first time, representatives of six out of seven acochlidian families [22] are analysed in the context of a broad taxon sampling that includes other meiofaunal slugs (Philinoglossa praelongata, Philine exigua, Smeagol phillipensis) and most euthyneuran sub-groups. Furthermore, the potentially related Gascoignella nukuli (as a representative of Platyhedylidae) and an undescribed species of Aitengidae are included in the present study. Since there is no fossil record of Acochlidia or any other mesopsammic Euthyneura, we apply a molecular clock approach to estimate divergence times for these groups. On the basis of our phylogenetic hypothesis we discuss evolutionary trends and potential consequences for euthyneuran classification in general.

\section{Results}

\section{Neighbournet analysis}

The neighbournet graph created by SplitsTree 4 (see Additional File 1) visualises a generally high conflict in 
the data (shown by a netlike structure with edges of similar length), and high substitution rates displayed by long terminal branches in many taxa. There is no cladesupporting pattern for the monophyly of Opisthobranchia or of Pulmonata on the basis of our dataset. Of the major traditional heterobranch taxa only Acteonoidea and Nudipleura show a clear split support (visualised by long parallel edges); some split support is present for Pyramidelloidea, Cephalaspidea s.s., Anaspidea, Umbraculoidea, pteropod Gymnosomata and Thecosomata, Amphiboloidea and Siphonarioidea. No pattern supporting any of the other opisthobranch or pulmonate groups can be found, mainly due to affinities of individual species to neighbouring groups. No split pattern indicates a relationship between the different meiofaunal heterobranchs such as Acochlidia, Smeagol phillipensis and Philinoidea (Philinoglossa praelongata and Philine exigua) (see Additional File 1).

The monophyly of the Acochlidia receives no split support. A very weak signal supports a grouping of Acochlidia together with some pulmonate taxa, but there is no indication for affinities to other opisthobranch taxa. The acochlidian subgroups Hedylopsacea and Microhedylacea receive no split support, due to some common support for Hedylopsis (Hedylopsacea) and Asperspina (Microhedylacea). The enigmatic Aitengidae sp. receives split support grouped with acochlidian Pseudunelidae and Acochlidiidae, and shows no affinity to Sacoglossa or Cephalaspidea.

\section{Phylogenetic analysis}

Examination of differences in incongruence length between the four genetic markers - 18S rRNA, $28 \mathrm{~S}$ rRNA, 16S rRNA and cytochrome $c$ oxidase subunit I (COI) - using the ILD-test implemented in PAUP* [36] revealed that the phylogenetic signal is improved in the combined data set ( $\mathrm{p}$-value of 0.01 ). Thus a concatenated dataset was used for phylogenetic analyses. The likelihood values of the different partitions of the dataset were compared via the Akaike Information Criterion (AIC) and the separation into 5 partitions (one each for $18 \mathrm{~S}, 28 \mathrm{~S}$ and 16S; COI separated in the two partitions $1^{\text {st }}$ and $2^{\text {nd }}$ position and $3^{\text {rd }}$ position) improved the likelihood significantly (see Additional File 2). The dataset aligned with MAFFT, masked with Gblocks and analysed in 5 partitions led to the best likelihood value, thus it is presented herein as the most probable phylogenetic hypothesis based on our data (see Figure 1). For comparison of the different analytical approaches and the resulting differences in tree topology and related support values, see Table 1.

The Euthyneura form a monophyletic group without significant bootstrap support (BS) in ML-analyses, or posterior probability (PP) in Bayesian analyses. They do not include the Acteonoidea (sister to "lower heterobranch" Rissoelloidea) in most of our analyses, but include the Pyramidelloidea and Glacidorboidea as sister group to Amphiboloidea. Within the Euthyneura the Opisthobranchia clearly result as non-monophyletic. At the basis of the Euthyneura the Nudipleura split off, with high internal support. The clade of the remaining euthyneuran taxa receives good support (85 BS/1.0 PP). First, an opisthobranch clade (no significant BS/1.0) is composed of Umbraculoidea, Runcinacea, Cephalaspidea s.s., Anaspidea and Pteropoda, with Umbraculoidea as the most basal branch. The runcinid Runcina africana forms the sister group to the Anaspidea and the well backed (82/1.0) Pteropoda (Gymnosomata and Thecosomata), and the above combined are sister to the remaining Cephalaspidea s.s., with high support for monophyly of Cephalaspidea s.s. (100/1.0). Internally the Cephalaspidea s.s. are poorly resolved, and their internal topology differs between the RAxML and Bayesian analyses (see Table 1). The mesopsammic Philine exigua and Philinoglossa praelongata do not form a clade: $P$. praelongata clusters with Scaphander lignarius, whereas no clear sister group relationship could be identified for $P$. exigua.

The Pulmonata as traditionally defined result as nonmonophyletic due to the inclusion of the opisthobranch groups Sacoglossa and Acochlidia and of the "lower" heterobranch Pyramidelloidea and Glacidorboidea. The pulmonate clade is significantly supported $(75 / 1.0)$, but internally characterised by an unstable topology, with no or low support concerning the sister group relationships between the major groups. Siphonarioidea and Sacoglossa form a clade (lacking significant support) sister to the remaining taxa (see Figure 1). In the analyses of the ALISCORE dataset Siphonarioidea form the most basal group, followed by a split-off of the Sacoglossa (see Table 1). The monophyletic Sacoglossa (98/1.0) combine clades with shelled and shell-less representatives, with Gascoignella nukuli (Platyhedylidae) as the most basal offshoot of the latter. Siphonarioidea + Sacoglossa are recovered as sister group to a clade composed of (Glacidorboidea + (Amphiboloidea + Pyramidelloidea $)+$ (Hygrophila + (Eupulmonata + Acochlidia)). Apart from Acochlidia, the monophyly of all higher taxa is well supported: Amphiboloidea (100/1.0), Pyramidelloidea (99/ 1.0), Hygrophila (86/1.0) and Eupulmonata (93/1.0). However, relations between these taxa are poorly resolved, not supported, and vary within the different analyses (see Table 1). In all our analyses Amphiboloidea cluster with Glacidorboidea and Pyramidelloidea. Thus Thalassophila (= Siphonarioidea and Amphiboloidea) and Basommatophora (= Thalassophila and Hygrophila) are left as polyphyletic. The Eupulmonata (Stylommatophora, Systellommatophora, Ellobioidea, Trimusculoidea and Otinoidea) are recovered sister to 


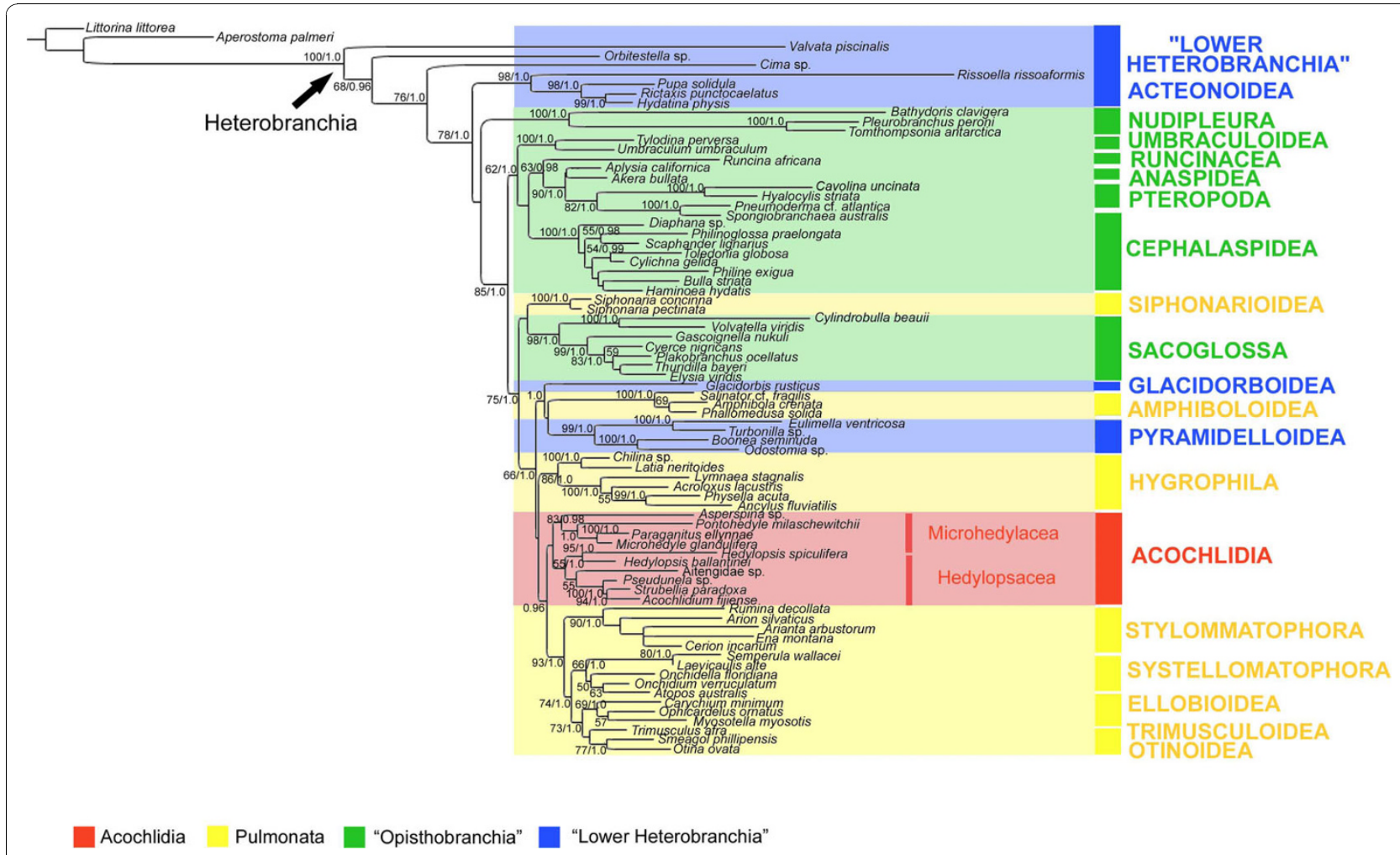

Figure 1 Origin of Acochlidia within Heterobranchia. RAxML analysis based on the combined dataset (18S, 28S, 16S, COI), masked with Gblocks. Bootstrap support and posterior probabilities given (only BS $\geq 50$ and PP $\geq 0.95$ are considered relevant and thus shown).

Table 1 Summary of the different analyses conducted

\begin{tabular}{|c|c|c|c|c|}
\hline $\begin{array}{l}\text { Sequence } \\
\text { alignment/ } \\
\text { masking/ } \\
\text { phylogenetic } \\
\text { analysis }\end{array}$ & $\begin{array}{l}\text { Model of } \\
\text { sequence } \\
\text { evolution }\end{array}$ & $\begin{array}{l}\text { Length of } \\
\text { alignment }\end{array}$ & $\begin{array}{l}\text { Monophyly of Acochlidia and sister group } \\
\text { relationship }\end{array}$ & $\begin{array}{l}\text { Changes within the tree topology compared } \\
\text { to Figure } 1\end{array}$ \\
\hline $\begin{array}{l}\text { MAFFT + Gblocks } \\
+ \text { RAxML }\end{array}$ & $\begin{array}{l}\text { GTRCAT } \\
\text { GTR + } \\
\text { GAMMA }\end{array}$ & $3641 \mathrm{bp}$ & see Figure 1 & see Figure 1 \\
\hline $\begin{array}{l}\text { MAFFT + } \\
\text { ALISCORE + } \\
\text { RAxML }\end{array}$ & $\begin{array}{l}\text { GTRCAT } \\
\text { GTR }+ \\
\text { GAMMA }\end{array}$ & 3926 bp & $\begin{array}{l}\text { Acochlidia monophyletic (no BS support) } \\
\text { Aitengidae basal within Hedylopsacea; Acochlidia } \\
\text { sister to (Hygrophila + (Glacidorboidea + } \\
\text { (Amphiboloidea + Pyramidelloidea))) (no BS } \\
\text { support) }\end{array}$ & $\begin{array}{l}\text { Anaspidea non-monophyletic; different internal } \\
\text { topology of Cephalaspidea s.s. (Philine exigua } \\
\text { basal to remaining taxa); Siphonarioidea and } \\
\text { Sacoglossa form no clade, but Siphonarioidea + } \\
\text { (Sacoglossa + remaining pulmonate taxa) }\end{array}$ \\
\hline $\begin{array}{l}\text { MAFFT + Gblocks } \\
+ \text { MrBayes }\end{array}$ & $\begin{array}{l}\text { GTR + G } \\
+I\end{array}$ & $3641 \mathrm{bp}$ & $\begin{array}{l}\text { Acochlidia monophyletic (no significant PP); sister } \\
\text { group to Eupulmonata ( } 0.96 \text { PP) }\end{array}$ & $\begin{array}{l}\text { basal tritomy within Euthyneura: (Acteonoidea + } \\
\text { Rissoelloidea)/Nudipleura/remaining Euthyneura; } \\
\text { different internal topology of Cephalaspidea s.s. } \\
\text { (Philine exigua basal to remaining taxa), } \\
\text { ((Glacidorboidea + Amphiboloidea) + } \\
\text { Pyramidelloidea) }\end{array}$ \\
\hline $\begin{array}{l}\text { MAFFT + } \\
\text { ALISCORE + } \\
\text { MrBayes }\end{array}$ & $\begin{array}{l}\text { GTR + G } \\
+1\end{array}$ & 3926 bp & $\begin{array}{l}\text { Acochlidia monophyletic (no significant PP) } \\
\text { Aitengidae basal within Hedylopsacea; Acochlidia } \\
\text { sister to (Hygrophila + (Glacidorboidea + } \\
\text { Amphiboloidea + Pyramidelloidea)) (no significant } \\
\text { PP) }\end{array}$ & $\begin{array}{l}\text { Anaspidea non-monophyletic; different internal } \\
\text { topology of Cephalaspidea s.s. (Philine exigua } \\
\text { basal to remaining taxa); Siphonarioidea and } \\
\text { Sacoglossa form no clade, but Siphonarioidea + } \\
\text { (Sacoglossa + remaining pulmonate taxa); } \\
\text { Nudipleura form a basal clade with (Acteonoidea } \\
\text { + Rissoelloidea) }\end{array}$ \\
\hline
\end{tabular}

The table lists the different methods of masking the alignment, phylogenetic approaches and models of sequence evolution used for the different analyses, as well as the resulting differences in tree topology (bootstrap support = BS; posterior probability $=\mathrm{PP}$ ). 
Acochlidia. Within Eupulmonata Stylommatophora (90/ 1.0) form the basal group; Systellommatophora (no significant BS/1.0) is sister to a clade Ellobioidea + (Trimusculoidea + Otinoidea), the latter comprising Smeagol phillippensis and Otina ovata.

Acochlidia are recovered as monophyletic but with no significant support. The internal phylogeny of the Acochlidia is composed of the two monophyletic traditional suborders Hedylopsacea (with Hedylopsidae, Pseudunelidae and Acochlidiidae) and Microhedylacea (with Asperspinidae and Microhedylidae including Ganitidae), and is congruent with the morphology-based phylogeny of Acochlidia proposed by Schrödl and Neusser [22]. Additionally the enigmatic Aitengidae sp. clusters within the Hedylopsacea as sister group to Pseudunelidae and Acochlidiidae (see Figure 1) or basal within Hedylopsacea.

In analyses of Gblock datasets Acochlidia are sister to Eupulmonata (see Figure 1), in ALISCORE based analyses they cluster sister to Hygrophila + (Glacidorboidea + Amphiboloidea + Pyramidelloidea) (see Table 1). To assess the level of confidence of the "best" tree (i.e. pulmonate relationship of Acochlidia), we calculated the $\mathrm{p}$-values of an alternative topology (Acochlidia cluster within Opisthobranchia) in combination with the "best" tree topology. Based on the resulting p-values of the AU test the alternative hypothesis is highly significantly rejected $(\mathrm{AU}$ value $=0)$.

\section{Molecular clock}

The phylogenetic hypothesis obtained with the software BEAST (see Figure 2) based on the concatenated fourmarker Gblocks dataset largely confirms the topology obtained from RAxML and MrBayes (see Figure 1). Based on the three fossil calibration points the Euthyneura originated already in the Palaeozoic, probably in the Carboniferous or Permian. The diversification of Euthyneura with the rise of many extant taxa started approximately in the late Palaeozoic (Permian) and major divergence events occurred in the Mesozoic. On the basis of our analysis the pulmonate clade (also including Sacoglossa, Acochlidia, Pyramidelloidea and Glacidorboidea) first appeared in the late Palaeozoic to early Mesozoic, approximately at the Permian/Triassic transition. The split between Eupulmonata and Acochlidia took place in the Mesozoic, between the Triassic and Jurassic periods. The diversification of Acochlidia is estimated to have happened in the Jurassic with the split between Hedylopsacea and Microhedylacea. Aitengidae split off from Pseudunelidae and Acochlidiidae in the Cretaceous. The transition to limnic habitats within Acochlidiidae appears as a comparatively recent event dating to the Palaeogene.

According to our data, major opisthobranch groups originated also in the Mesozoic (e.g. Cephalaspidea s.s. estimated to the Jurassic, Sacoglossa approximately Triassic/early Jurassic period, Pteropoda to the Cretaceous).

For comparison and to evaluate the impact of removing ambiguous parts of the alignment on molecular clock analyses, we repeated the analysis with the raw (i.e. uncut) alignment of our data (again using the concatenated four-marker dataset in five partitions). Even though the topology varied slightly from the one in the previous analysis, the estimated divergence times stayed surprisingly constant, supporting the rough estimate given above.

\section{Discussion}

\section{Implications for the phylogeny of Heterobranchia}

Our results on the origin of Acochlidia - in congruence with previous molecular studies on Euthyneura based on the same molecular markers $[14,17]$ - necessitate the reconsideration of current classification concepts. Redefinitions below aim to observe continuity in traditional nomenclature and cause the unavoidable minimum of changes in terminology.

\section{Euthyneura}

The monophyly of Euthyneura (traditionally uniting Opisthobranchia and Pulmonata) has been widely accepted and well supported [13,18,37], even though their eponymous apomorphy - the euthyneury - has been revealed as convergent development $[1,2]$. Euthyneuran monophyly was recently questioned due to inclusion of "lower Heterobranchia" Pyramidelloidea unresolved within Pulmonata $[13,15,16]$ or sister to Amphiboloidea $[14,17]$. Some other morphological studies place Pyramidelloidea as sister to Euthyneura [10,33]. Dinapoli and Klussmann-Kolb [14] argued to include them within Euthyneura, which has also been supported by morphological analysis [13]. Latest molecular data on Pyramidelloidea support an euthyneuran origin and indicate a relationship with Glacidorboidea and Amphiboloidea [38]. Our data again recovers Pyramidelloidea as sister to Amphiboloidea within pulmonates (see Figure 1), but with no significant support. In addition to nucleotide sequences [[14,15,17], present study], data from mitochondrial gene arrangements [16], a "morpho-molecular" synapomorphy (20 bp deletion in 16S rRNA helix of Pyramidelloidea and Euthyneura, see [11]) as well as morphology (presence of a euthyneurous nervous system with giant nerve cells) all support the inclusion of Pyramidelloidea within Euthyneura. When first describing Glacidorboidea, Ponder [39] placed them within Pulmonata and discussed a relationship to Amphiboloidea. However, Haszprunar [2] moved them to "lower Heterobranchia". The first molecular data on Glacidorboidea confirmed a pulmonate relationship [14]. This is again supported by our data. 


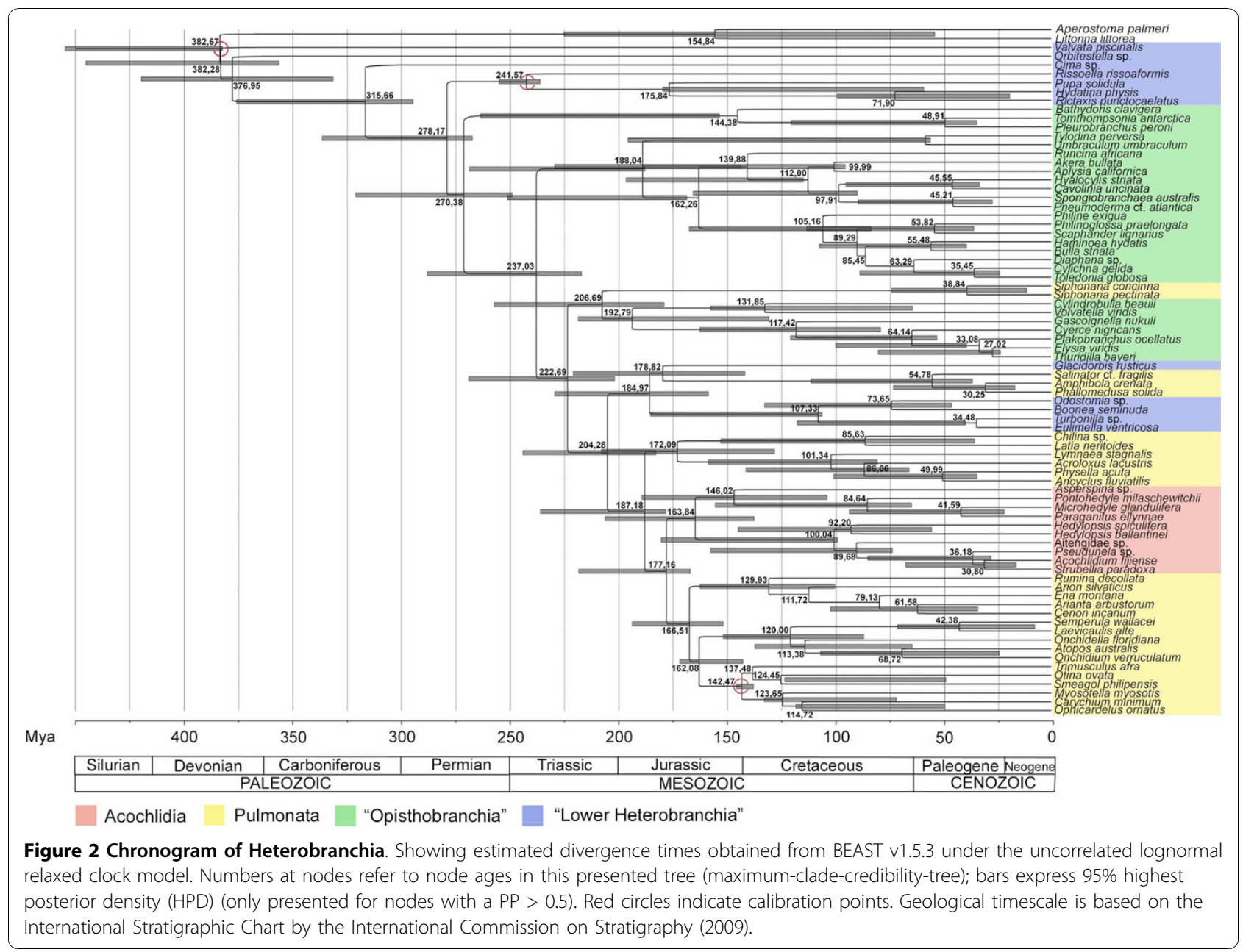

\section{"Opisthobranchia"}

While the monophyly of several opisthobranch subgroups (e.g. Pteropoda, Cephalaspidea s.s., Nudipleura) receives good support, the monophyly of the Opisthobranchia in a traditional sense is rejected in all recent studies, regardless of whether the latter are molecular or morphological [e.g. $[14,17,40]]$. This is confirmed by our multi-locus molecular approach (see Figure 1) and supported by the results of the AU test. Thus, "Opisthobranchia" as traditionally defined should be considered as non-monophyletic.

As in previous studies we can clearly distinguish at least two clades (i.e. basal Nudipleura and Umbraculoidea + Runcinacea + Anaspidea + Pteropoda + Cephalaspidea s.s.) within "Opisthobranchia" that lead towards the pulmonate level of organisation.

Only one of our analyses indicates the Acteonoidea sister to Nudipleura (see Table 1). This clade that had resulted repeatedly in molecular studies with still limited "lower heterobranch" taxon sampling, either in a derived position $[34,41]$ or as a basal offshoot within Euthyneura $[15,17]$. A recent molecular phylogeny on Acteonoidea suggest a common origin with lower heterobranch Rissoelloidea and a sister group relationship to Nudipleura [42]. While the basal position of Acteonoidea was commonly accepted $[33,40]$, some authors doubted the basal position of Nudipleura, which was originally considered as a highly derived taxon, and suspect rate heterogeneity and deviant base composition as causing this unnatural grouping $[17,34]$. Based on potential synapomorphies in the reproductive system (presence of a ciliary stripe within the ampulla, androdiaulic or triaulic pallial gonoduct), Ghiselin [43] already suggested a relationship between Acteonoidea and Nudipleura. However, Acteonoidea form a well-supported "lower heterobranch" clade with Rissoelloidea, (see Figure 1; Table 1), confirming results by Aktipis et al. [44] and Dinapoli and Klussmann-Kolb [14]. The latter authors also recovered Nudipleura as the first offshoot of Euthyneura, which is confirmed by our study. Salvini-Plawen and Steiner [10] grouped Umbraculoidea with Nudipleura, but none of the recent molecular or morphological studies support such a relationship $[17,33,34]$. 
A common clade including Umbraculoidea, Anaspidea, Cephalaspidea s.s. and Pteropoda was already well supported in previous molecular analyses [9,14,17], and monophyly of a clade Anaspidea + Pteropoda received strong support in one previous study [12]. The present results confirm Cephalaspidea s.s., including Diaphanidae, but excluding Runcinidae as suggested in a previous analysis [45]. In our study Runcina africana groups with Anaspidea and Pteropoda, as in the Bayesian analysis of the concatenated 18S rRNA, 28S rRNA and COI dataset of the more comprehensive cephalaspidean phylogeny by Malaquias et al. [45]. The latter authors thus proposed to reinstate Runcinacea as a taxonomic category equivalent to Cephalaspidea s.s.. However, different analyses of the same authors led to different placements of Runcinacea, e.g. as sister to the remaining Cephalaspidea s.s.; hence the group's origin was left unresolved. Surprisingly our study indicates independent origins for the mesopsammic Philine exigua (Philinidae) and Philinoglossa praelongata(Philinoglossidae). The internal topology of Cephalaspidea s.s. is weakly supported in our study, but a more complete cephalaspidean sampling also rendered Philinoidea paraphyletic (based on $18 \mathrm{~S}$ and 28S) [45].

Based on our results and in congruence with the topology in previous studies [14,17], we suggest to unite Umbraculoidea, Anaspidea, Runcinacea, Pteropoda and Cephalaspidea s.s. in the new clade Euopisthobranchia (see Figure 3), presenting a monophyletic remainder of the "Opisthobranchia" as traditionally defined. Previous studies $[9,18]$ discussed the gizzard (i.e. a muscular oesophageal crop lined with cuticula) with gizzard plates as homologous apomorphic structures supporting a clade composed of Cephalaspidea s.s., Pteropoda and Anaspidea. A gizzard with gizzard plates probably originated in herbivorous taxa in which it worked like a grinding mill, thus might be secondarily reduced in carnivorous groups within Cephalaspidea s.s. and Gymnosomata [9]. Klussmann-Kolb and Dinapoli [9] considered the gizzard in Umbraculoidea as non-homologous with the one in the previous groups, on account of the absence of gizzard plates or spines. This contradicted Salvini-Plawen and Steiner [10], who had proposed the gizzard to be a synapomorphy of the larger clade of Paratectibranchia (Pteropoda, Cephalaspidea and Anaspidea) and Eleutherobranchia, secondarily lost in Nudipleura but still present in Umbraculoidea. As coded in Wägele and Klussmann-Kolb [33], our phylogenetic hypothesis supports homology of the gizzard in Umbraculoidea with the gizzard with gizzard plates and spines in the other euopisthobranchian taxa. Thus, the structure is proposed as a synapomorphy of Euopisthobranchia.

\section{"Pulmonata"}

The monophyly of Pulmonata as traditionally defined has been well supported in morphological analyses (see e.g. $[10,13])$ and molecular studies $[8,46]$. However, doubts have arisen recently due to molecular studies which recovered additional taxa (e.g. Pyramidelloidea, Sacoglossa or Acochlidia) within "Pulmonata" [14,17], or to novel studies based on mitochondrial gene arrangements [16] which rendered "Pulmonata" polyphyletic. Based on our phylogenetic hypothesis (Figure 1) "Pulmonata" as traditionally defined is non-monophyletic due to the inclusion of Pyramidelloidea, Glacidorboidea, Sacoglossa and Acochlidia. On the premise of monophyletic Euthyneura, with basal Nudipleura and monophyletic Euopisthobranchia (see discussion above), the remaining euthyneuran taxa necessarily form a clade, in our study supported with maximum posterior probability (1.0) and significant bootstrap support (75\%) (see Figure 1). Even though the topology within this pulmonate clade is unstable and not well resolved (see Table1), for practical reasons and due to the assumptions of monophyletic Euthyneura and Euopisthobranchia we suggest the new taxon Panpulmonata to unite Siphonarioidea, Sacoglossa, Glacidorboidea, Pyramidelloidea, Amphiboloidea, Hygrophila, Acochlidia and Eupulmonata (see Figure 3). The scientific meaning of the name "Pulmonata" and the corresponding major feature of those animals being "air-breathers" surely are not applicable to the novel panpulmonate groups Acochlidia, Sacoglossa and Pyramidelloidea, but also not for traditional pulmonate taxa such as Siphonarioidea or Hygrophila, most members of which lack permanently air-filled lungs. The term Panpulmonata is chosen for continuity in terminology. While certain pulmonate groups are well supported morphologically and molecularly (i.e. Eupulmonata and Hygrophila), unambiguous synapomorphies for Panpulmonata are hard to find (see discussion below).

Siphonarioidea and Sacoglossa form a clade sister to the remaining Panpulmonata (see Figure 3). While Haller [47] classified Siphonarioidea as opisthobranchs (e.g. on account of the presence of a gill), nowadays they are usually considered as "primitive" pulmonates, either grouped at the basis of the remaining Pulmonata $[37,46]$ or united with Amphiboloidea as basommatophoran Thalassophila [48]. Molecular studies rendered Basommatophora and Thalassophila paraphyletic and indicated a close relationship of Siphonarioidea to Sacoglossa, either both within Opisthobranchia [16], at their basis [15], or basal to the remaining Pulmonata [[14,17], present study] as sister groups or separate clades. However, all studies show weak support at these nodes, and the positions of siphonariids and sacoglossans as well as 


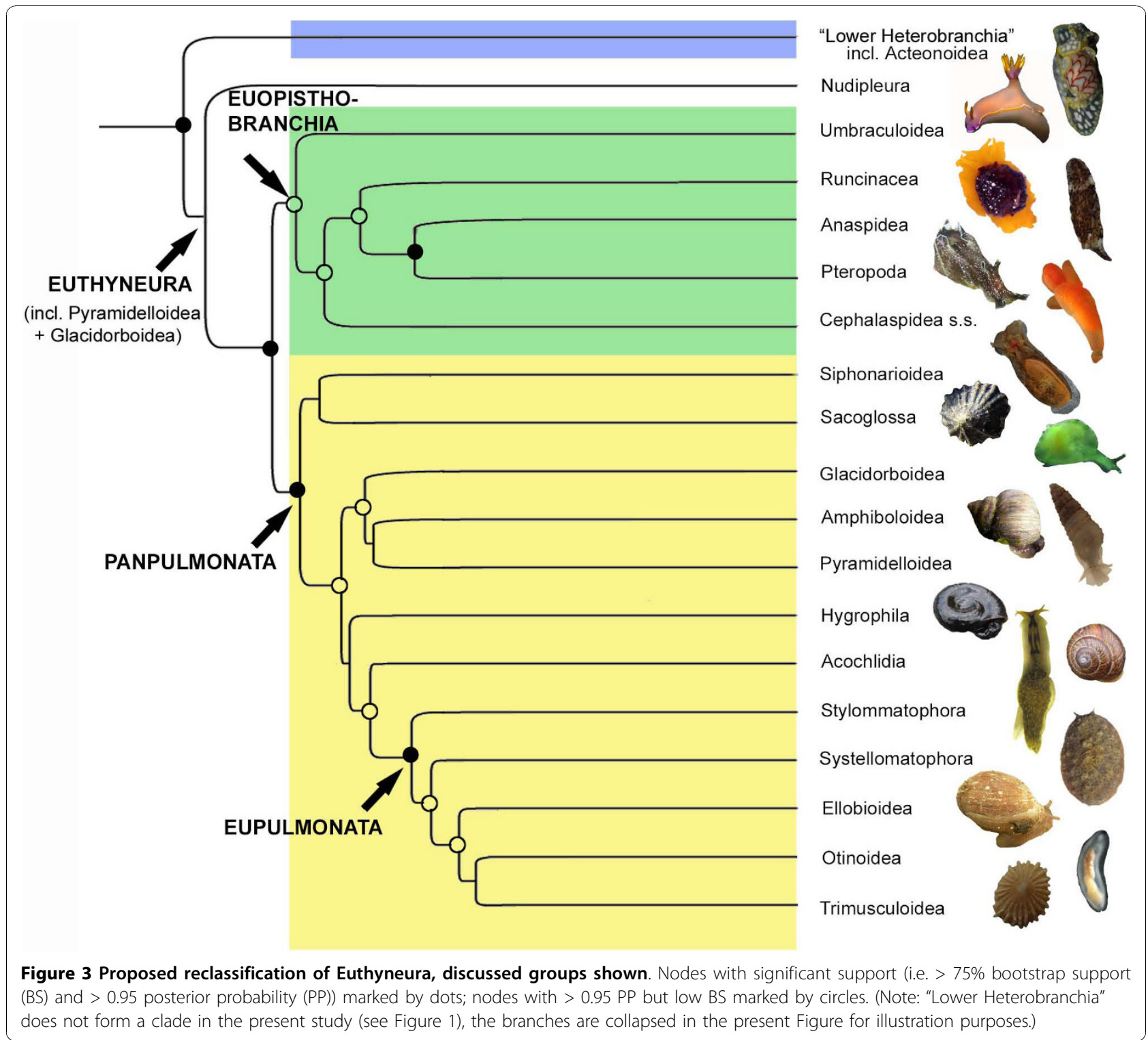

their relationship still need confirmation by other character sets and improved taxon sampling.

In the present study the monophyly of Sacoglossa is well supported and also the split into shelled Oxynoacea and Plakobranchacea is well backed (see Figure 1). Both suborders are also well supported morphologically [4]. Platyhedylidae stand basally within the latter, as sister to Limapontioidea plus the remaining Plakobranchoidea. Jensen [4] placed Platyhedylidae at the basis of Plakobranchoidea but already pointed out their unclear relationships.

Hygrophila, Amphiboloidea and Eupulmonata are all well supported monophyletic groups in the present study, but their sister group relationships are not well resolved and receive little to no support.

\section{Origin of Acochlidia}

All groups previously discussed as having an affinity or closer relationship to Acochlidia were included in the present study to reveal their phylogenetic relationships. Only the enigmatic Rhodopemorpha are lacking, but a recent molecular phylogeny based on nuclear and mitochondrial markers shows no affinities between Acochlidia and Rhodopemorpha [49], and the morphological characters common to both groups can be explained as convergent developments (see discussion below and [22]). A phylogenetic relationship of Acochlidia with the diaphanid Toledonia, which was suggested based on similar radula characteristics [25], is rejected by the present molecular data and also resulting from morphological analyses [22]. Morphological studies indicated a 
common origin for small Runcinacea and Cephalaspidea (i.e. mesopsammic Philinoglossa and Philine exigua) with Acochlidia [22,33]. However, Schrödl and Neusser [22] showed the liability of the topology to inclusion of other interstitial taxa such as Rhodope and Platyhedyle, which always resulted as direct sister groups to Acochlidia in various analyses. The authors thus concluded that the convergent adaptations to the interstitial habitat (e.g. worm-shaped body, development of spicules, loss of pigmentation) mask the true phylogenetic signal. This interpretation is supported by our SplitsTree analysis (see Additional File 1) and the present molecular results (see Figure 1), which clearly signal independent evolutionary origins for all the different mesopsammic Heterobranchia included here.

Previous molecular analyses placed the Acochlidia basally in an unresolved opisthobranch level [34] or surprisingly clustered them in an unresolved pulmonate relationship [17]. While any opisthobranch affinities are rejected based on split support (see Additional File 1), based on the AU test and based on phylogenetic analysis, the pulmonate relationship of Acochlidia is confirmed in this study (see Figure 1), which presents a much better acochlidian taxon sampling and highly likely topology within Acochlidia (see discussion below). Even though support for their direct sister group relationships are low and the topology varies between the different analyses, all analyses performed in the present study placed Acochlidia within pulmonates (see Table 1). This grouping based on molecular markers requires a re-evaluation of morphological characters and earlier, potentially biased homology assumptions, and a search for potential synapomorphies uniting Acochlidia with pulmonates. Three anatomical characters are generally accepted as true synapomorphies of the "Pulmonata" as traditionally defined: the pallial cavity opening by means of a pneumostome, presence of a procerebrum (with cerebral gland and double cerebro-connectives) and the existence of medio-dorsal (cerebral) bodies [13,50].

1) Pallial cavity opening by means of a pneumostome

Although denied by some earlier authors, the pulmonary cavity of "Pulmonata" is today generally considered as homologous to the pallial cavity of non-pulmonate gastropods [51]. Whereas the loss of a gill and the presence of a "lung" certainly is a matter of multiple convergence paralleled in several prosobranch clades, the acquisition of a pneumostome (i.e. a small respiratory opening) is considered as synapomorphic for "Pulmonata" $[13,18,48]$. Dayrat and Tillier [[13], see also references therein] pointed out that the pneumostome of Siphonarioidea is not contractile, and their phylogenetic hypothesis [13] favoured homology with the pneumostome of the remaining Pulmonata. On the other hand, at least some siphonariids are reported to open and close their pneumostome [e.g. [52]]. A morphocline from a wide open pallial cavity to a narrow, nearly closed one (i.e. presence of pneumostome) is present in both "Opisthobranchia" and "Pulmonata"; thus the presence of a pneumostome in general cannot be considered as a pulmonate synapomorphy [53]. Barker [53] also questioned the synapomorphic contractile pneumostome, which might have evolved independently in different pulmonate taxa, e.g. in Eupulmonata and some Siphonarioidea. The presence of a small opening seems to be variable, indeed, and might depend on the habitat. For example, the truly subtidal marine Williamia (Siphonarioidea) have a wide opening [54], while intertial Siphonaria have a small one (i.e. a contractile or noncontractile pneumostome). The opening is wide also in subtidal shell-bearing Sacoglossa [3], whereas the pallial cavity is usually reduced in shell-less Sacoglossa. Pyramidelloidea also have a wide opening. In general within "Pulmonata" the "lung" undergoes a series of reductions; e.g., the tiny Smeagol climoi only has a small pallial cavity without respiratory function [51], as do larger Onchidiidae. A small, reduced pallial cavity can still be found in the quite basal acochlidian Hedylopsis ballantinei [55] (as Hedylopsis sp.), while all remaining Acochlidia studied so far entirely lack such a cavity $[22,30]$. All hedylopsacean nervous systems described in detail contain an osphradial ganglion $[25,29,31,32]$, which can be interpreted as a remainder of an osphradium that was reduced in the course of the reduction of the pallial cavity. A group of derived, benthic and limnic acochlidians have developed a sensory, osphradium-like organ [56] like the one reported for the basal ellobiid Ovatella [57].

\section{2) Presence of a procerebrum}

The procerebrum of "Pulmonata" is defined as an accessory lobe linked to the cerebral ganglion via two connectives, associated to the optic, tentacular and peritentacular nerves [58]. Its homology with the opisthobranch rhinophoral ganglion has long been discussed $[2,47,59]$. The configuration of the cerebral nerves and associated ganglia is complex in Acochlidia. The labiotentacular nerve arises ventrally from the cerebral ganglion; the rhinophoral ganglion usually gives rise to the rhinophoral nerve (with Hancock's nerve branching off), and the optic ganglion to the optic nerve $([31,32,56]$ and own unpublished data). However, in Pseudunela cornuta the optic nerve splits off from the rhinophoral nerve, and no nerves arise from the optic ganglion [29]. A similar arrangement occurs in Hedylopsis spiculifera and $H$. ballantinei, except that the optic ganglion is lacking $[25,60]$. In the microhedylaceans Pontohedyle and Microhedyle the rhinophoral nerve emerges directly from the cerebral ganglion, and eyes nestle directly on it ([27], own unpublished data); thus the additional ganglion might refer to either the 
rhinophoral or the optic ganglion. Tillier et al. [46] discussed a potential homology between the optic ganglion in "Opisthobranchia" and the pulmonate procerebrum. In Acochlidia double cerebral connectives could be identified for the rhinophoral ganglion in Tantulum elegans [60], the optic (but not the rhinophoral) in Strubellia paradoxa [56], and for the unclear optic/rhinophoral ganglion in Pontohedyle milaschewitchii and Microhedyle glandulifera ([27] as rhinophoral ganglion, own unpublished data). The variable development of cerebral features in Acochlidia makes homologisation difficult at this time. Rhinophoral and optic ganglia are closely related to and might develop from the cerebral ganglion, and they share common features with the pulmonate procerebrum. Based on our phylogenetic hypothesis, the plesiomorphic state for Panpulmonata might be separate rhinophoral and optic ganglia that have been fused various times independently. However, the presence of socalled "globineurons" - neurons with densely packed, small, round nuclei - in Eupulmonata [58,61] appears to be a synapomorphy for this clade.

Additionally, the presence of a cerebral gland - a small, tube-like structure involved in the formation of the procerebrum - is considered as characteristic for the pulmonate nervous system $[58,61]$. This ectodermal structure may form a tube-like process from the procerebrum towards the lateral head region, or it may be reduced to a small epithelial cavity attached or enclosed within the procerebrum [58,61]. No structure similar to the cerebral gland has been described for Acochlidia, but due to the small size of the cerebral gland and the previously unknown pulmonate affinities of Acochlidia it might have been overlooked in morphological studies; hence, ultrastructural reinvestigations of acochlidian nervous systems are needed in the future. The cerebral gland is lacking also in other pulmonate taxa, e.g. Amphiboloidea [58], which either raises doubts about their pulmonate affinities [46] or suggests that the structure might have been lost secondarily. Moreover, Tardy $[62,63]$ described a similar invagination involved in the formation of the rhinophoral ganglion in different nudibranchs. In light of the present phylogenetic hypothesis, with Nudipleura as the most basal euthyneuran offshoot, this might indicate that the formation of the rhinophoral ganglion (and the homologous procerebrum) involving an ectodermal invagination is plesiomorphic within Euthyneura, and that there are remnants (or paedomorphotic reinstatements) of this structure in adults of (some) pulmonate taxa.

\section{3) Presence of medio-dorsal (= cerebral) bodies}

(Medio-)dorsal bodies (also termed cerebral bodies) are endocrine organs situated dorsally of the cerebral ganglia in "Pulmonata" [13], but considerable variation exists within the main pulmonate groups as regards the structure and innervation of the dorsal bodies $[58,61,64]$. Similar structures closely attached to the cerebral ganglia have been found in several Acochlidia: First described as "dorsal bodies" [25], they were later renamed "lateral bodies" by Neusser et al. [60], due to their more lateral position to the central nervous system and the unclear homology to pulmonate dorsal bodies. Since dorsal bodies in Pulmonata play a role in female reproduction [64], they might be fully developed in female adults only, thus might have been overlooked in some studies of gonochoristic acochlidian species or of hermaphrodites with "sex change". Further ultrastructural data on acochlidian "lateral bodies" and their potentially neurosecretory function are needed to evaluate homology with pulmonate structures. Moreover, pulmonate dorsal bodies might be homologous to the juxtaganglionar organs of some opisthobranchs [60], and thus might represent a plesiomorphic character of Panpulmonata and a potential synapomorphy of Euthyneura.

In addition, the presence of an unpaired dorsal jaw, which probably originated through the fusion of the paired lateral jaws [65], has been discussed as a potential synapomorphy of "Pulmonata" $[18,48]$. The presence of a pair of dorso-lateral jaws is a plesiomorphic character state for Euthyneura [13,65], but that condition has been reduced various times independently in "Opisthobranchia" and "Pulmonata" [18]. A dorsal, unpaired jaw might have evolved at the basis of Panpulmonata, and then have been secondarily reduced various times independently (e.g. in Onchidiidae, Amphibola) [18]. In Acochlidia, jaw-like structures are reported only for the derived microhedylacean family Ganitidae (as paired jaws), and as unclear "cuticular elements" for Microhedyle glandulifera (see [22] for citations). According to the derived position of Ganitidae in morphological [22] and molecular analyses (present study), these structures may represent either secondary developments (potentially related to the specialised dagger-shaped radula) or paedomorphic structures; however, studies of Acochlidia larvae are still overdue.

The only potential synapomorphy of "Opisthobranchia" is the presence of a rhinophoral nerve with a thickened basis (i.e. rhinophoral ganglion) and of associated sensory structures such as Hancock's organ [66]. Based on our phylogenetic hypothesis the presence of a rhinophoral nerve has to be considered as a plesiomorphic character within Euthyneura, and thus for Panpulmonata. The rhinophoral ganglion, and potentially the optic ganglion, is considered as homologous with the pulmonate procerebrum. Rhinophoral nerve and Hancock's organ have been reduced various times independently, probably correlated with the reduction of the rhinophores and/or habitat changes. 
In summary, we are currently unable to find clear morphological synapomorphies which support a placement of Acochlidia within pulmonate taxa, as sister to Eupulmonata. In the light of our phylogenetic hypothesis, conventional pulmonate synapomorphies appear to be plesiomorphies or convergences within pulmonate taxa. On the other hand, no morphological characters currently contradict that molecular phylogenetic hypothesis, nor do they favour any alternative relationships, since morphological characters common to the mesopsammic heterobranchs are shown to be convergent developments, and the potential synapomorphy of Acochlidia with "Opisthobranchia" has to be considered as plesiomorphic.

The aberrant morphology of Acochlidia in relation to its proposed sister groups remains problematic. In his ontological studies on the nudibranch Aeolidiella alderi, Tardy [62] reported an abnormal development in some larvae that leads to a visceral hump separated from the head-foot complex in juvenile stages, thereby closely resembling external morphology in Acochlidia (see fig. 20 in [62]). According to Tardy [62] these abnormal developmental forms are also known from pulmonate Stylommatophora. Progenesis is discussed as a principle in the evolution of meiofaunal taxa [67], and acochlidian morphology might have evolved by retention of the juvenile characters of an aberrant developmental form of an early pulmonate.

\section{Monophyly and phylogeny of Acochlidia}

The monophyly of Acochlidia is well supported morphologically $[20,22,24]$ and also backed by previous molecular studies $[17,34]$. Our study, which includes all valid acochlidian families except for the monotypic Tantulidae, also recovers Acochlidia as monophyletic but with low posterior probability and bootstrap support. The low bootstrap values for Acochlidia and some internal acochlidian taxa (e.g. Hedylopsacea) might be caused by their relatively early (Mesozoic) divergence times (see Figure 2): recent acochlidian taxa probably constitute but a remnant of much larger diversity in evolutionary history.

The acochlidian internal topology confirms the morphological analysis of Schrödl and Neusser [22], showing the same family relationships, but with better resolution within Microhedylacea: the genus Pontohedyle splits off at the basis of the Microhedylidae s.l. (including Ganitidae) with the closely related genera Microhedyle and Paraganitus. The hedylopsacean family Acochlidiidae includes the genera Strubellia and Acochlidium as proposed by Arnaud et al. [68] and Schrödl and Neusser [22]. Puzzling is the position of the enigmatic Aitengidae within Acochlidia, either as sister to Pseudunelidae and limnic Acochlidiidae (see Figure 1) or basal within
Hedylopsacea (see Table 1). Aitengidae shows some of the general, but not unique, features of Acochlidia, such as the lack of a shell, reduction of mantle cavity, the praepharyngeal (circumpharyngeal) nerve ring, and the radula with a descending and ascending limb. This taxon also shares some features with limnic Acochlidiidae: the radula with a strong rhachidian tooth specialised in egg feeding, as also reported for Strubellia sp. [56]; the large, internal lateral eyes closely associated with the cerebral ganglia; and the presence of a foot groove and a branched digestive gland like reported for the genera Acochlidium and Palliohedyle [69,70]. On the other hand, Aitengidae lacks several acochlidian characteristics: the division of the body into head-foot complex and visceral hump; presence of 1-2 head appendages (with characteristic innervation of the rhinophores); and the ability to retract the head-foot complex into the visceral hump. However, in the absence of a separated visceral hump $A$. ater is able to retract its head under the notum. The presence of spicules is confirmed for Aitengidae sp., and the "parasites" described for A. ater might represent spicules instead (T. Neusser, pers. comm.). Re-examination of the doubtful "ascus" in $A$. ater is necessary; examination of Aitengidae sp. showed no true (i.e. sacoglossan-like) ascus containing old teeth, just a radula slightly bent at the end (own unpublished data). The presence of an ascus is currently accepted as a unique synapomorphy of Sacoglossa [4], and any sacoglossan relationship is clearly rejected by SplitsTree analysis (see Additional file 1) and phylogenetic analyses in the present study.

At the present stage of knowledge, molecular data suggests an inclusion of Aitengidae within Acochlidia, as sister to Pseudunelidae and Acochlidiidae. Detailed description by semithin serial sectioning and 3D reconstruction of the Aitengidae sp. used in the present study, together with focused redescription of $A$. ater, are needed as a basis to evaluating phylogenetic relationships of Acochlidia and Aitengidae in the future. This should be supported by a comprehensive molecular phylogeny of Acochlidia, including the two known species of Aitengidae.

\section{Evolutionary traits in Euthyneura Invasion of the interstitial habitat}

Our study supports earlier assumptions that invasion of the interstitial habitat has occurred various times independently within the Euthyneura [22,68,71], probably by benthic, sand-dwelling or temporarily (i.e. juvenile) mesopsammic ancestors of the nudibranch genera Embletonia and Pseudovermis, the cephalaspidean Philinoglossa and Philine exigua, the sacoglossan Platyhedyle, some members of the Rhodopemorpha incertae sedis (Helminthope and some Rhodope), and the Acochlidia 
$[22,68]$. The pulmonate genus Smeagol is found in gravel or pebble beaches on the undersides of stones; due to the relatively large body size in some species (e.g. up to $14 \mathrm{~mm}$ in $S$. manneringi[72]), it cannot be generally assigned to the meiofauna.

Major convergent adaptations to this spatially limited and unstable habitat are the worm-shaped body, loss of shell, and reduction of head appendages and pigmentation [21]. The development of subepidermal, calcareous spicules in Acochlidia, Rhodopemorpha and potentially Platyhedyle can also be considered as an adaptation to the interstitial habitat, probably serving to stabilise certain body parts during movements through the interstices [27], even though the occurrence of spicules is not limited to the mesopsammon. As far as is known, Acochlidia represent the most successful group of Heterobranchia in the mesopsammon concerning species diversity and abundance [27]. Key features for their success probably are an initial heterochronic miniaturisation and two different evolutionary trends towards a rapid, imprecise sperm transfer [23]. Additionally, adaptation to (temporarily) brackish waters with the development of a complex excretory system in Hedylopsacea $[22,29]$ allows colonisation of shallow sands with freshwater impact (by groundwater or rain), overcoming limitations to deeper, truly marine sands.

\section{Colonisation of freshwater and terrestrial habitats}

It is undisputed and again confirmed by the present study that the "Pulmonata" have a marine origin [see e. g. $[17,18]]$. The hygrophilian radiation in the freshwater system is the most successful within "Pulmonata" [17], in terms of diversity and abundance, but not a unique event in pulmonate evolutionary history. Dinapoli and Klussmann-Kolb [14] already showed that the invasion of freshwater within pulmonate taxa took place at least twice, in Hygrophila and in the enigmatic Glacidorbis. According to our study, the colonisation of freshwater in Panpulmonata has occurred at least one more time in Acochlidia. Schrödl and Neusser [22] showed that within Acochlidia the freshwater colonisation already occurred twice independently, with a radiation of the Indo-Pacific Acochlidiidae and the single Caribbean Tantulum elegans (Tantulidae, not included in the present study). Thus, the development of a complex kidney within Hedylopsacea [29] as an adaptation to (temporarily) brackish water can be considered as a precursor to the invasion of limnic systems in Acochlidia. Acochlidian invasion of freshwater originated probably from a mesopsammic ancestor with temporary freshwater tolerance [32], or via a semi-terrestrial habitat as reported for Aitengidae [35]. Our study thus highlights the high diversity and flexibility of pulmonate habitats ranging from marine to temporarily brackish, permanently brackish, limnic and terrestrial environments. The still enigmatic Aiteng ater (Aitengidae) lives "amphibiously" and tolerates marine to brackish waters, but there are no observations of these animals truly leaving the water [35]. The species' mangrove habitat is comparable to that of representatives of, e.g., the pulmonate Onchidiidae, and is classified as marginal zones from which the transition to terrestrial habitat probably originated [17]. Similar to the limnic habitat, terrestrial environments have been colonised various times independently [53]. The present study indicates a least four independent pathways to the terrestrial habitat: in Amphiboloidea, Stylommatophora, Systellommatophora and Ellobioidea.

\section{Molecular clock and estimation of divergence times in Acochlidia}

The use of molecular clocks to estimate divergence times is controversially debated, due to conflicting results from different studies and disparities with paleontological or archaeological data [73-76]. Criticism focuses on the major problems such as faulty calibration, impact of rate heterogeneity among lineages, and "time dependency of molecular rates" [73,75-77]. Some of the problems could be solved by the relaxed clock approach [78], and despite all pitfalls and criticism, molecular clock approaches have helped considerably to reveal the evolutionary history of life, especially when it comes to divergence times of groups with poor or no fossil record [75,76,79]. Thus, we consider it a valuable methodology to roughly estimate divergence times for tiny, sluggish gastropods for which there is no fossil record. Molecular clock dating stands and falls with the accuracy with which genetic distances can be estimated [80]; thus we consider the removal of ambiguous (i.e. potentially non-homologous) sites from the alignment as problematic. It seems common use to run the molecular clock analyses with reduced datasets (e.g. [14,81-83]), but the crucial question, how this will affect the molecular dating, has remained unaddressed. The exclusion of highly saturated positions - e.g., in some cases the $3^{\text {rd }}$ codon position of the COI sequence (see e.g. [84]) - can be justified by the biasing effect of saturation on the molecular clock. It can be argued that ambiguous parts of the alignment are often highly variable and might suffer from saturation, but on the other hand the exclusion of a series of non-saturated sites might result in underestimated divergence times. However, our Beast analysis of the raw, uncut dataset provided estimations of divergence times very similar to those from the Gblocks dataset (not shown). Nevertheless, we recommend to critically compare data from masked and raw alignments for molecular clock analyses, and to stay mindful of the potentially underestimating effect on divergence times.

The only molecular clock data on Heterobranchia [14] available prior to the present study suffers from 
unreliable calibration, which is considered as the most sensible and critical part of divergence time estimations [76]. There is no objective way to assign fossils to a certain point of a stem line in a recent phylogeny, thus the age of the fossil has to be taken as the minimum age of the split between the extant taxon it is assigned to and its sister group [80]. In [14] the fossil ages were assigned to the diversification of Heterobranchia, Acteonoidea and Omalogyridae, respectively, rather than to the splits from the corresponding sister groups, which led, e.g., to the surprising Pre- to early Cambrian split between Vetigastropoda and Apogastropoda. Our molecular clock was calibrated to the split between Caenogastropoda and Heterobranchia; thus molecular dating of this node is biased (i.e. depends directly on calibration features). However, fossil data shows two clearly different lineages by the mid-Devonian, thus indicating a pre- or early Devonian split of Apogastropoda [85,86]. According to our study euthyneuran gastropods already emerged in the Palaeozoic Permian, diverting from the "Lower Heterobranchia", but all major radiations of Euthyneura occurred in the early Mesozoic. According to paleontological data the oldest opisthobranchs appeared in the Triassic (about 220 Mya), the earliest pulmonates in the Jurassic (about 190 Mya) $[85,86]$.

Based on their phylogenetic hypothesis from morphological data and the fossil record of cephalaspidean outgroups, Schrödl and Neusser [22] suspected a Jurassic time frame for the origin of Acochlidia. Their inferred sister group relationships are different from the present study, but the early divergence time is supported by our molecular clock approach, which places the origin of Acochlidia in the late Triassic to early Jurassic and their major diversification in the Jurassic. In the present study the Eupulmonata as sister group to Acochlidia show similar origin and diversification times, and so do the Hygrophila. Tillier et al. [46] inferred divergence times from branch lengths in a molecular distance tree (based on partial $28 \mathrm{~S}$ sequences), indicating a similar Jurassic time frame for Eupulmonata and slightly younger for Hygrophila. This corresponds with fossil data, which reports a first occurrence in the late Jurassic (approx. 150 Mya) [46]. Based on fossils, diversification times of eupulmonate groups such as Stylommatophora can be dated to the late Cretaceous, when most extant families appear [87].

According to our data most acochlidian families appeared in the Jurassic or Cretaceous, only Ganitidae, Pseudunelidae and Acochlidiidae have a Palaeogene origin. These old splits on the family and even genus levels (see Hedylopsis, Figure 2, diverging in the Cretaceous) might indicate either that the extant diversity of Acochlidia is only a small remnant of high diversity in former times, or that known acochlidian diversity is just the tip of the iceberg still waiting to be discovered.
Based on fossil data the major diversification of "opisthobranch" taxa in a traditional sense took place comparatively recently, at the beginning of the Cenozoic (around $60 \mathrm{Mya}$ ), with the first records of Sacoglossa, Anaspidea and Thecosomata [86]. However, due to more or less reduced shells the fossilization probability is low. Our study suggests that most extant "opisthobranch" taxa, e.g. Sacoglossa, Cephalaspidea s.s., Pteropoda, Umbraculoidea and Anaspidea, have a Mesozoic origin. Ambiguous is the basal euthyneuran position of the Nudipleura and the resulting estimates of an old age (late Palaeozoic) and diversification (middle Mesozoic). This contradicts previous molecular clock analyses on Nudipleura, which indicated a Triassic origin and Jurassic diversification [82]. These discrepancies clearly result from major differences in tree topology (basal vs. derived position). Moreover, while our study includes only three nudipleuran representatives (poor ingroup taxon sampling), Göbbeler's and Klussmann-Kolb's [82] analysis lacks comprehensive heterobranch outgroup sampling. Future studies are needed to resolve the origin of Nudipleura within the Heterobranchia.

\section{Conclusions}

Our multi-locus molecular study including six out of seven acochlidian families and the recently established Aitengidae confirms a pulmonate relationship of Acochlidia, which was traditionally placed within Opisthobranchia. The enigmatic Aitengidae cluster within Acochlidia. Previously assumed morphological synapomorphies of Pulmonata (pallial cavity with pneumostome, procerebrum with cerebral gland, and presence of medio-dorsal bodies) appear as either homoplastic or plesiomorphic in light of the present phylogenetic hypothesis, as does the potential opisthobranch synapomorphy (presence of rhinophoral nerve). At present, morphological characters neither justify a placement of Acochlidia within Pulmonata, nor do they favour any opisthobranch relationships that would contradict the molecular hypothesis. The aberrant acochlidian morphology might have resulted from ancestral progenesis and paedomorphic retention of the morphology of an abnormally developed juvenile.

The present study once more underlines the respective non-monophyly of Euthyneura, Opisthobranchia and Pulmonata as defined traditionally. We demonstrate the necessity for inclusion of small, enigmatic groups to solve deep-level phylogenetic relationships, and highlight that the "pulmonate" and "opisthobranch" phylogenies cannot be solved independently from each other. Clarification of remaining enigmas such as Rhodopemorpha, and of well supported taxa with unclear relationships such as Pyramidelloidea or Sacoglossa, is needed for future advances. The reclassification suggested herein 
defines 1) Euthyneura as including Pyramidelloidea and Glacidorboidea; 2) Euopisthobranchia as including Umbraculoidea, Cephalaspidea s.s., Runcinacea, Anaspidea and Pteropoda, but excluding Acteonoidea and Nudipleura, as well as Sacoglossa and Acochlidia; and 3) Panpulmonata as composed of Siphonarioidea, Sacoglossa, Hygrophila, Amphiboloidea, Pyramidelloidea, Glacidorboidea, Eupulmonata and Acochlidia. The present results based on standard molecular markers require confirmation from other character sets (e.g. rare genomic changes, mitochondrial gene arrangements, additional molecular markers) and careful (re-)examination of morphological characters and homology assumptions in the light of the new phylogenetic hypothesis. Our molecular clock analysis estimates a Mesozoic origin for all major panpulmonate taxa. The poorly supported topology within Panpulmonata might be promoted by the old age of this group, which potentially stands for a series of radiation and extinction events in history, resulting in poor taxon representation in present times.

The present study shows that the mesopsammon was colonised various times independently within Euthyneura, resulting in a series of convergent adaptations to the interstitial habitat. The inclusion of Acochlidia within pulmonate taxa extends the structural and biological diversity of the pulmonate clade, which exhibits remarkable flexibility in habitat choice, with various transitions from marine to limnic and terrestrial habitats.

\section{Methods \\ Taxon sampling}

A total of 78 gastropod taxa were investigated in the present study. As new material, nine acochlidian taxa and five additional enigmatic and hard-to-obtain euthyneuran taxa with potential acochlidian relationships were included (see Table 2). Specimens were collected by hand or extracted from sand samples following the method described by Schrödl [88], usually anaesthetised with $\mathrm{MgCl}_{2}$, and fixed in $96 \%$ ethanol. Reference specimens and DNA vouchers of sequences generated in this study are deposited at the Bavarian State Collection for Zoology (ZSM); sampling localities, reference material and DNA Bank accession numbers (http://www.dnabank-network.org) of our own data are listed in Table 2. Other sequences were retrieved from GenBank (for accession numbers see Table 3). Outgroups were chosen to include all major euthyneuran and several further heterobranch taxa. Special focus was given to mesopsammic representatives and groups previously discussed as potentially related to Acochlidia. Of these potential relatives only Rhodopemorpha are missing in our study, but a Rhodopemorpha-Acochlidia relationship can be clearly rejected based on molecular markers [49].

\section{DNA extraction, PCR and sequencing}

Genomic DNA was extracted from tissue samples of the foot or from entire specimens using the DNeasy Blood and Tissue Kit (Qiagen, Hilden Germany). Four markers were amplified: nuclear $18 \mathrm{~S}$ rRNA (approx. $1800 \mathrm{bp}$ ), 28S rRNA (approx. $1020 \mathrm{bp}$ ), mitochondrial 16S rRNA (approx. 300-400 bp), and cytochrome $c$ oxidase subunit I (COI - approx. $650 \mathrm{bp}$ ). For PCR protocols and primers used, see additional file 3. Successfully amplified PCR products were purified using ExoSapIT (USB, Affymetrix, Inc.). Cycle sequencing and the sequencing reaction were performed by the sequencing service of the Department of Biology Genomic Service Unit (GSU) of the Ludwig-Maximilians-University Munich, using Big Dye 3.1 kit and an ABI 3730 capillary sequencer. All fragments were sequenced in both directions using the PCR primers. All sequences have been deposited at GenBank (see Table 3 for accession numbers). The Gblock alignment and the resulting tree were deposited in TreeBASE (http://www.treebase.org, accession number 10801).

\section{Sequence editing and alignment}

All sequences generated in this study were checked for contaminations with BLAST searches [89] implemented in the GenBank database on the NCBI webpage (http:// blast.ncbi.nlm.nih.gov/Blast.cgi). Reconciliation of forward and reverse reads was carried out in BioEdit 7.0.5. [90]. MAFFT v6 [91] was used to generate sequence alignments for each gene region, using the default settings (automatically chosen models for $18 \mathrm{~S}, 28 \mathrm{~S}$, COI: FFT-NS-i; for 16S: L-INS-i). The alignment of the protein coding COI gene was corrected manually according to the amino acids. The individual MAFFT alignments were parsed 1) using Gblocks [92,93] with the default settings for less stringent selection, 2) with ALISCORE v1.0 [94] using the default parameters, or c) left unmasked.

\section{Phylogenetic analysis}

For an a priori analysis of variation in the phylogenetic signal a split-decomposition analysis was performed using SplitsTree v4.6 [95].

The best-fit model of nucleotide substitution for each gene was selected using Modeltest 3.7 [96] via the Akaike Information Criterion (AIC). The incongruence length difference (ILD) test [97] was carried out in Paup $4.0 \mathrm{~b} 10$ [36]. This test was conducted with heuristic searches and 100 replicates to evaluate incongruence between single markers. 
Table 2 Information on the material generated for the present study

\begin{tabular}{|c|c|c|c|c|}
\hline Taxon & Family & Locality & Museums Nr. & $\begin{array}{l}\text { DNA Bank voucher } \\
\text { Nr. }\end{array}$ \\
\hline \multicolumn{5}{|l|}{ Acochlidia } \\
\hline Hedylopsis spiculifera & Hedylopsidae & $\begin{array}{l}\text { Istria Croatia/Corse France, Mediterranean } \\
\text { Sea }\end{array}$ & $\begin{array}{l}\text { ZSM Mol 20080951/ZSM Mol } \\
20080955\end{array}$ & $\begin{array}{l}\text { AB35081816 } \\
\text { AB35081817 }\end{array}$ \\
\hline Hedylopsis ballantinei & Hedylopsidae & Sinai, Egypt, Red Sea & ZSM Mol 20090244 & AB34858170 \\
\hline Pseudunela sp. & Pseudunelidae & Mounparap Island, Vanuatu, Pacific & ZSM Mol 20080393 & AB35081809 \\
\hline Strubellia paradoxa & Acochlidiidae & Ambon, Indonesia, Indo-Pacific & Berlin Moll 193944 & AB34858174 \\
\hline Acochlidium fijiense & Acochlidiidae & Vitilevu, Fiji, Pacific & ZSM Mol 20080063 & AB34404244 \\
\hline Asperspina sp. & Asperspinidae & Kamtschatka, Russia, North Pacific & ZSM Mol 20090171 & AB35081833 \\
\hline Microhedyle glandulifera & Microhedylidae & Istria, Croatia, Mediterranean Sea & ZSM Mol 20081019 & AB35081799 \\
\hline $\begin{array}{l}\text { Pontohedyle } \\
\text { milaschewitchii }\end{array}$ & Microhedylidae & Istria. Croatia, Mediterranean Sea & $\begin{array}{l}\text { ZSM Mol 20080054/ZSM Mol } \\
20080925\end{array}$ & AB34404241 \\
\hline Paraganitus ellynnae & Ganitidae & Guadalcanal, Solomons, Pacific & ZSM Mol 20080170 & AB34404203 \\
\hline \multicolumn{5}{|l|}{ Sacoglossa } \\
\hline Gascoignella nukuli & Platyhedylidae & $\begin{array}{l}\text { Pak Phanang Bay, Thailand, Gulf of } \\
\text { Thailand }\end{array}$ & ZSM Mol 20090182 & AB344011928 \\
\hline Volvatella viridis & Volvatellidae & Bonotsu, Kagoshima, Japan, Pacific & - & - \\
\hline Aitengidae sp. & Aitengidae & $\begin{array}{l}\text { Hisamatsu, Miyako Island, Okinawa, Japan, } \\
\text { Pacific }\end{array}$ & - & - \\
\hline \multicolumn{5}{|l|}{ Cephalaspidea } \\
\hline Philine exigua & Philinidae & Guadalcanal, Solomons, Pacific & ZSM Mol 20080752 & AB34401927 \\
\hline Philinoglossa praelongata & Philinoglossidae & Istria, Croatia, Mediterranean Sea & ZSM Mol 20080917 & AB34500041 \\
\hline
\end{tabular}

The table lists the species names, collecting localities, reference numbers of museum vouchers (ZSM = Bavarian State Collection for Zoology; Berlin = Museum of Natural History, Berlin) and DNA vouchers deposited in the DNA Bank of the ZSM.

Maximum likelihood analyses were performed using RAxML 7.0.3 [98] adapting the program parameters to the alignment as described in the manual ("hard \& slow way" - with 10 parsimony starting trees and 6 different rate categories). Additionally 200 multiple inferences were executed on the original alignment and 1000 bootstrap replicates were generated. Analyses were run under the GTR Gamma model as recommended in the manual [98] and the caenogastropod taxa Littorina littorea and Aperostoma palmeri were defined as outgroups. The alignment was analysed in different partition sets: one partition, two partitions $(18 \mathrm{~S}+28 \mathrm{~S}+$ $16 \mathrm{~S}$ combined; COI separate), three partitions (18S + $28 \mathrm{~S}+16 \mathrm{~S}$ combined; COI with codons partitioned to $1^{\text {st }}+2^{\text {nd }}$ separate from $3^{\text {rd }}$ ), four partitions (separated by gene regions), and five partitions (18S, $28 \mathrm{~S}, 16 \mathrm{~S}$, COI $1^{\text {st }}+2^{\text {nd }}$, COI $\left.3^{\text {rd }}\right)$. To test whether partitioning significantly improves the likelihood values of the dataset, we compared the likelihood values of all partitions via the Akaike Information Criterion.

Bayesian phylograms were generated from the Gblocks and ALISCORE alignments with MrBayes 3.1.2 [99]. The general time-reversible model was used for both datasets, with invariant site frequency and gamma-shape parameter estimated from the data $(G T R+I+G)$. The 'shape', 'proportion of invariant sites', 'state frequency' and 'substitution rate' parameters were estimated for each gene separately. Each codon position in the amino- acid coding COI was also allowed to have different parameters; hence the alignments had six partitions of parameters. Two parallel runs were made for $5 \times 10^{6}$ generations (with a sample frequency of 1000), using a default value of four Markov chains. Quality and ESS values (effective sampling size) of each run were checked in Tracer 1.5.3. The first 2000 trees for each run were discarded to ensure that the four chains reached stationarity. The consensus tree and posterior probabilities were computed from the remaining 6000 trees (3000 trees $\times 2$ runs).

To evaluate support for our tree topology an alternative topology (grouping Acochlidia with Opisthobranchia) was tested in comparison to the "best" tree topology by using the Approximately Unbiased Test [100]. The hypothetic topology was computed with RAxML [98] using the -g option for the constraint ML tree. The p-values of the sitewise log likelihoods combined with the "best" topology were estimated using Treefinder [101].

\section{Molecular clock}

Approximate divergence times were calculated using the relaxed molecular clock approach [78] implemented in the software BEAST 1.5.3 [102]. For molecular clock analysis the concatenated Gblock-dataset was analysed in five partitions as for the phylogenetic analyses.

Calibration points were chosen for groups with stable and well supported nodes in the phylogenetic 
Table 3 GenBank accession numbers of the sequences used in the present study

\begin{tabular}{|c|c|c|c|c|c|c|}
\hline Taxon & Family & Species & $18 S$ & $28 \mathrm{~S}$ & $16 S$ & $\mathrm{COI}$ \\
\hline \multirow[t]{2}{*}{ Caenogastropoda } & Cyclophoridae & Aperostoma palmeri & DQ093435 & DQ279983 & DQ093479 & DQ093523 \\
\hline & Littorinidae & Littorina littorea & X91970 & AJ488672 & DQ093481 & AY345020 \\
\hline \multirow[t]{9}{*}{ "Lower" Heterobranchia } & Orbitestellidae & Orbitestella sp. & EF489352 & EF489377 & EF489333 & EF489397 \\
\hline & Valvatidae & Valvata piscinalis & FJ917223/FJ917222 & FJ917224 & FJ917248 & FJ917267 \\
\hline & Cimidae & Cima sp. & FJ917206.1 & FJ917228.1 & FJ917260.1 & FJ917279.1 \\
\hline & Rissoellidae & Rissoella rissoaformis & FJ917214.1 & FJ917226.1 & FJ917252.1 & FJ917271.1 \\
\hline & Pyramidellidae & Turbonilla sp. & EF489351 & EF489376 & EF489332 & EF489396 \\
\hline & Pyramidellidae & Boonea seminuda & AY145367 & AY145395 & AF355163 & - \\
\hline & Pyramidellidae & Eulimella ventricosa & FJ917213.1 & FJ917235.1 & FJ917255.1 & FJ917274.1 \\
\hline & Pyramidellidae & Odostomia sp. & AY427526.1 & AY427491.1 & FJ917256.1 & FJ917275.1 \\
\hline & Glacidorbidae & Glacidorbis rusticus & FJ917211.1 & FJ917227.1 & FJ917264.1 & FJ917284.1 \\
\hline \multirow[t]{3}{*}{ Acteonoidea } & Acteonidae & Pupa solidula & AY427516 & AY427481 & EF489319 & DQ238006 \\
\hline & Aplustridae & Hydatina physis & AY427515 & AY427480 & EF489320 & GQ845174.1 \\
\hline & Acteonidae & Rictaxis punctocaelatus & EF489346 & EF489370 & EF489318 & EF489393 \\
\hline \multirow[t]{3}{*}{ Nudipleura } & Bathydorididae & Bathydoris clavigera & AY165754 & AY427444 & AF249222 & AF249808 \\
\hline & Pleurobranchidae & Tomthompsonia antarctica & AY427492 & AY427452 & EF489330 & DQ237992 \\
\hline & Pleurobranchidae & Pleurobranchus peroni & AY427494 & AY427455 & EF489331 & DQ237993 \\
\hline \multirow[t]{2}{*}{ Umbraculoidea } & Umbraculidae & Umbraculum umbraculum & AY165753 & AY427457 & EF489322 & DQ256200 \\
\hline & Tylodinidae & Tylodina perversa & AY427496 & AY427458 & - & AF249809 \\
\hline \multirow[t]{2}{*}{ Anaspidea } & Akeridae & Akera bullata & AY427502 & AY427466 & AF156127 & AF156143 \\
\hline & Aplysiidae & Aplysia californica & AY039804 & AY026366 & AF192295 & AF077759 \\
\hline \multirow[t]{4}{*}{ Pteropoda } & Pneumodermatidae & Pneumoderma cf. atlantica & DQ237970 & DQ237989 & - & DQ238003 \\
\hline & Pneumodermatidae & Spongiobranchaea australis & DQ237969 & DQ237988 & - & DQ238002 \\
\hline & Cavoliniidae & Hyalocylis striata & DQ237966 & DQ237985 & - & - \\
\hline & Cavoliniidae & Cavolinia uncinata & DQ237964 & DQ237983 & - & DQ237997 \\
\hline Runcinacea & Runcinidae & Runcina africana & DQ923473 & DQ927240 & - & DQ974680 \\
\hline \multirow[t]{8}{*}{ Cephalaspidea s.s. } & Bullidae & Bulla striata & DQ923472.1 & DQ986694.1 & DQ986632.1 & DQ986567.1 \\
\hline & Phillinoglossidae & Philinoglossa praelongata & AY427510 & AY427475 & HQ168411* & - \\
\hline & Scaphandridae & Scaphander lignarius & EF489348 & EF489372 & EF489324 & - \\
\hline & Haminoeidae & Haminoea hydatis & AY427504 & AY427468 & EF489323 & DQ238004 \\
\hline & Philinidae & Philine exigua & HQ168425* & HQ168438* & HQ168412* & HQ168450* \\
\hline & Diaphanidae & Diaphana sp. & - & EF489373 & EF489325 & EF489394 \\
\hline & Diaphanidae & Toledonia globosa & EF489350 & EF489375 & EF489327 & EF489395 \\
\hline & Cylichnidae & Cylichna gelida & EF489349 & EF489374 & EF489326 & - \\
\hline \multirow[t]{7}{*}{ Sacoglossa } & Volvatellidae & Volvatella viridis & HQ168426* & HQ168439* & HQ168413* & HQ168451* \\
\hline & Cylindrobullidae & Cylindrobulla beauii & EF489347 & EF489371 & EF489321 & - \\
\hline & Platyhedylidae & Gascoignella nukuli & HQ168427* & HQ168440* & HQ168414* & HQ168452* \\
\hline & Caliphyllidae & Cyerce nigricans & AY427500 & AY427463 & EU140843 & DQ237995 \\
\hline & Plakobranchidae & Plakobranchus ocellatus & AY427497 & AY427459 & DQ480204 & DQ237996 \\
\hline & Elysiidae & Thuridilla bayeri & AF249220 & AY427461 & DQ480206 & DQ471271 \\
\hline & Elysiidae & Elysia viridis & AY427499 & AY427462 & AY223398 & DQ237994 \\
\hline Sacoglossa (?) & Aitengidae & Aitengidae sp. & HQ168428* & HQ168441* & HQ168415* & HQ168453* \\
\hline \multirow[t]{9}{*}{ Acochlidia } & Hedylopsidae & Hedylopsis ballantinei & HQ168429* & HQ168442* & HQ168416* & HQ168454* \\
\hline & Hedylopsidae & Hedylopsis spiculifera & HQ168430* & HQ168443* & HQ168417* & HQ168455* \\
\hline & Pseudunelidae & Pseudunela sp. & HQ168431* & HQ168444* & HQ168418* & HQ168456* \\
\hline & Acochlidiidae & Strubellia paradoxa & HQ168432* & HQ168445* & HQ168419* & HQ168457* \\
\hline & Acochlidiidae & Acochlidium fijiense & HQ168433* & HQ168446* & HQ168420* & HQ168458* \\
\hline & Asperspinidae & Asperspina sp. & HQ168434* & HQ168447* & HQ168421* & - \\
\hline & Microhedylidae & Pontohedyle milaschewitchii & HQ168435* & AY427484 & HQ168422* & HQ168459* \\
\hline & Ganitidae & Paraganitus ellynnae & HQ168436* & HQ168448* & HQ168423* & HQ168460* \\
\hline & Microhedylidae & Microhedyle glandulifera & HQ168437* & HQ168449* & HQ168424* & HQ168461* \\
\hline
\end{tabular}


Table 3 GenBank accession numbers of the sequences used in the present study (Continued)

\begin{tabular}{|c|c|c|c|c|c|c|}
\hline \multirow[t]{2}{*}{ Siphonarioidea } & Siphonaridae & Siphonaria pectinata & U86321 & DQ279993 & AY377627 & AF120638 \\
\hline & Siphonaridae & Siphonaria concinna & EF489334 & EF489353 & EF489300 & EF489378 \\
\hline \multirow[t]{3}{*}{ Amphiboloidea } & Amphibolidae & Amphibola crenata & EF489337 & EF489356 & EF489304 & - \\
\hline & Amphibolidae & Phallomedusa solida & DQ093440 & DQ279991 & DQ093484 & DQ093528 \\
\hline & Amphibolidae & Salinator cf. fragilis & - & EF489355 & EF489303 & EF489381 \\
\hline \multirow[t]{6}{*}{ Hygrophila } & Latiidae & Latia neritoides & EF489339 & EF489359 & EF489307 & EF489384 \\
\hline & Chilinidae & Chilina sp. & EF489338 & EF489357 & EF489305 & EF489382 \\
\hline & Acroloxidae & Acroloxus lacustris & AY282592 & EF489364 & EF489311 & AY282581 \\
\hline & Lymnaeidae & Lymnaea stagnalis & EF489345 & EF489367 & EF489314 & EF489390 \\
\hline & Physidae & Physella acuta & AY282600 & EF489368 & AY651241 & AY282589 \\
\hline & Planorbidae & Ancylus fluviatilis & AY282593 & EF489365 & EF489312 & AY282582 \\
\hline \multirow[t]{5}{*}{ Stylommatophora } & Arionidae & Arion silvaticus & AY145365 & AY145392 & AY947380 & AY987918 \\
\hline & Helicidae & Arianta arbustorum & AY546383 & AY014136 & AY546343 & AY546263 \\
\hline & Enidae & Ena montana & AY546396 & - & AY546356 & AY546276 \\
\hline & Cerionidae & Cerion incanum & - & AY014060.1 & - & - \\
\hline & Subulinidae & Rumina decollata & - & $13794085: 464-1292$ & AY345050 & AY345050 \\
\hline \multirow[t]{5}{*}{ Systellommatophora } & Onchidiidae & Onchidium verruculatum (§) & AY427522 & AY427487 & EF489316 & EF489391 \\
\hline & Onchidiidae & Onchidella floridiana & AY427521 & AY427486 & EF489317 & EF489392 \\
\hline & Veronicellidae & Laevicaulis alte & X94270.1 & AY014151.1 & & \\
\hline & Veronicellidae & Semperula wallacei & - & DQ897671.1 & DQ897675.1 & DQ897673.1 \\
\hline & Rathouisiidae & Atopos australis & - & AY014152.1 & - & - \\
\hline Trimusculoidea & Trimusculidae & Trimusculus afra & EF489343 & - & EF489309 & EF489388 \\
\hline \multirow[t]{2}{*}{ Otinoidea } & Otinidae & Otina ovata & EF489344 & EF489363 & EF489310 & EF489389 \\
\hline & Smeagolidae & Smeagol phillipensis & FJ917210 & FJ917229 & FJ917263 & FJ917283 \\
\hline \multirow[t]{3}{*}{ Ellobioidea } & Carychiidae & Carychium minimum & EF489341 & EF489361 & EF489308 & EF489386 \\
\hline & Ellobiidae & Ophicardelus ornatus & DQ093442 & DQ279994 & DQ093486 & DQ093486 \\
\hline & Ellobiidae & Myosotella myosotis & EF489340 & EF489360 & AY345053 & EF489385 \\
\hline
\end{tabular}

Sequences generated within this study are marked with *; (§) in GenBank as "O. verrucosum", which is not a valid name, thus treated as O. verruculatum. (" - " indicates missing sequences).

hypothesis and decently documented fossil record with clear identification to recent taxa. Minimum constraints for three nodes were chosen based on the fossil record: 1) split between Caenogastropoda and Heterobranchia based on the oldest known fossil of the Heterobranchia (Palaeocarboninia janke) recorded from the Middle Devonian (390 Ma) [85]; 2) the split between Acteonoidea and its sister group based on acteonoid fossils with a minimum age of $240 \mathrm{Ma}$ ([103], A Nützel pers. comm.) and 3) the split of Ellobioidea and their sister group based on ellobiid fossils with a minimum age of $140 \mathrm{Ma}$ ([86], A Nützel pers. comm.). We calibrated using a hard minimum bound (i.e. the divergence data cannot be younger than the oldest known fossil); the probability that the divergence event occurred above the minimum date declines according to a gamma distribution, such that $95 \%$ of the posterior density falls within the range $[\mathrm{x}-$ $x+10 \%$ ] [see [104]]. Calibration nodes were not fixed as monophyletic.
The analyses were run with the relaxed uncorrelated lognormal clock model under the Yule process using the GTR $+\mathrm{G}+\mathrm{I}$ substitution model (chosen from Modeltest 3.7 [96] via the Akaike Information Criterion) for all markers. The MCMC was run ten times independently, generating $10^{6}$ generations each, and sampled every 1000 steps. The single runs were combined with LogCombiner 1.5.3, with the first $10^{5}$ samples each discharged as burn-ins. The runs were checked for quality and sufficient ESS (effective sample size) in Tracer 1.5.3. All trees were combined to produce a consensus tree using TreeAnnotator 1.5.3, with the first 1000 trees of each dataset discharged as burn-in.

To evaluate the potential effect on molecular dating of removing ambiguous sites from the alignment, the BEAST runs were repeated with the raw alignments (i.e. mainly uncut; only longer ends of some sequences removed due to the use of different primers) alignments, generating $10 \times 10^{6}$ generations and following the method described above. 


\section{Additional material}

Additional file 1: Neighbournet graph on the origin of Acochlidia. Generated with Splits Tree v4.6 from the concatenated, four marker dataset masked with Gblocks, visualising highly conflicting signal at the basis of the Acochlidia. Representatives of meiofaunal taxa highlighted in boldface, showing the absence of a common phylogenetic signal.

Additional file 2: Likelihood values of different partitions

Additional file 3: PCR protocols and primers used [105-107].

\section{Acknowledgements}

Prof. Dr. Gerhard Haszprunar (ZSM/LMU Munich) and three referees are kindly acknowledged for valuable discussion and for helpful comments on the manuscript. Timea P. Neusser and Bastian Brenzinger (both ZSM) contributed with their knowledge of acochlidian anatomy. Dr. Matthias Glaubrecht (Museum für Naturkunde Berlin), Dr. Alexander Martynov (Zoological Museum, Moscow State University) and Dr. Kees Swennen (Prince of Songkla University) kindly provided material for molecular analysis. Katharina Händeler (University of Bonn) is thanked for sharing mitochondrial data on Aiteng ater (Aitengidae), and Dr. Alexander Nützel (University of Munich) for critical evaluation of potential fossil calibration points. Special thanks go to Dr. Dirk Metzler (University of Munich) for introduction to and support in molecular clock analyses. Martin Spies (ZSM) kindly helped improving our English. This study was financed by a PhD scholarship from the Volkswagen foundation to KJ. Additional support for molecular analyses was provided by the DNA Bank Network (DFG grant INST 17818/1-1). Field work was supported by the German Research Foundation (DFG SCHR 667/4 to MS) and the GeoBioCenter ${ }^{\llcorner M U}$.

\section{Author details}

'Bavarian State Collection of Zoology, Münchhausenstr. 21, 81247 München, Germany. ${ }^{2}$ Department of Marine Ecosystems Dynamics, Atmosphere and Ocean Research Institute, University of Tokyo, 5-1-5 Kashiwanoha, Kashiwa, Chiba 277-8564, Japan. ${ }^{3}$ Conservation of Aquatic Biodiversity, Faculty of Agriculture, Okayama University, Tsushima-naka 1-1-1, Kita-ku, Okayama 7008530, Japan.

\section{Authors' contributions}

KMJ, MS, YK and HF sampled the material. KMJ, IS, TK and YK generated the molecular data. KMJ and YK conducted the phylogenetic and network analysis. KMJ performed the molecular clock approach. KMJ wrote the initial version of the manuscript; all authors contributed to the discussion of the results and the preparation of the final manuscript. MS planned and supervised the study. All authors have read and approved the final manuscript.

\section{Competing interests}

The authors declare that they do not have competing interests.

Received: 26 April 2010 Accepted: 25 October 2010

Published: 25 October 2010

\section{References}

1. Haszprunar G: The Heterobranchia - a new concept of the phylogeny of the higher Gastropoda. Z f zool Systematik u Evolutionsforschung 1985, 23:15-37.

2. Haszprunar G: On the origin and evolution of major gastropod groups, with special reference to the Streptoneura. J Molluscan Stud 1988, 54:367-441.

3. Mikkelsen PM: The evolutionary relationships of Cephalaspidea s.l. (Gastropoda: Opisthobranchia): a phylogenetic analysis. Malacologia 1996, 37:375-442.

4. Jensen KR: Phylogenetic systematics and classification of the Sacoglossa (Mollusca, Gastropoda, Opisthobranchia). Philos Trans R Soc Lond, Ser B: Biol Sci 1996, 351:91-122.
5. Wägele H, Willan RC: Phylogeny of the Nudibranchia. Zool J Linn Soc 2000, 130:83-181.

6. Klussmann-Kolb A: Phylogeny of the Aplysiidae (Gastropoda, Opisthobranchia) with new aspects of the evolution of seahares. Zool $\mathrm{Scr}$ 2004, 33:439-462.

7. Wollscheid-Lengeling E, Boore J, Brown W, Wägele H: The phylogeny of Nudibranchia (Opisthobranchia, Gastropoda, Mollusca) reconstructed by three molecular markers. Org Divers Evol 2001, 1:241-256.

8. Wade $\mathrm{CM}$, Mordan PB, Clarke B: A phylogeny of the land snails (Gastropoda: Pulmonata). Proc Biol Sci 2001, 268:413-422.

9. Klussmann-Kolb A, Dinapoli A: Systematic position of the pelagic Thecosomata and Gymnosomata within Opisthobranchia (Mollusca, Gastropoda) - revival of the Pteropoda. JZS 2006, 44:118-129.

10. Salvini-Plawen LV, Steiner G: Synapomorphies and plesiomorphies in higher classification of Mollusca. In Origin and evolutionary radiation of the Mollusca. Edited by: Taylor J. Oxford: Oxford University Press; 1996:29-51.

11. Thollesson M: Phylogenetic analysis of Euthyneura (Gastropoda) by means of the 16S rRNA gene: use of a 'fast' gene for 'higher-level' phylogenies. Proc R Soc Lond Ser B Biol Sci 1999, 266:75-83.

12. Dayrat $B$, Tillier $A$, Lecointre $G$, Tillier $S$ : New clades of euthyneuran gastropods (Mollusca) from 28S rRNA sequences. Mol Phylogen Evol 2001, 19:225-235.

13. Dayrat B, Tillier S: Evolutionary relationships of euthyneuran gastropods (Mollusca): a cladistic re-evaluation of morphological characters. Zool J Linn Soc 2002, 135:403-470.

14. Dinapoli A, Klussmann-Kolb A: The long way to diversity - Phylogeny and evolution of the Heterobranchia (Mollusca: Gastropoda). Mol Phylogen Evol 2010, 55:60-76.

15. Grande C, Templado J, Cervera JL, Zardoya R: Molecular phylogeny of the Euthyneura (Mollusca: Gastropoda). Mol Biol Evol 2004, 21:303-313.

16. Grande C, Templado J, Zardoya R: Evolution of gastropod mitochondrial genome arrangements. BMC Evol Biol 2008, 8:61.

17. Klussmann-Kolb A, Dinapoli A, Kuhn K, Streit B, Albrecht C: From sea to land and beyond-new insights into the evolution of euthyneuran Gastropoda (Mollusca). BMC Evol Biol 2008, 8:57.

18. Dayrat B, Tillier S: Goals and limits of phylogenetics. The euthyneuran gastropods. In Molecular systematics and phylogeography of Mollusks. Edited by: Lydeard C, Lindberg D. Washington, London: Smithonian Books; 2003:161-184.

19. Odhner N: Die Acochlidiaceen, eine eigentümliche OpisthobranchiatenGruppe. Basteria 1938, 3:5-11.

20. Wawra E: Zur Anatomie einiger Acochlidia (Gastropoda, Opisthobranchia) mit einer vorläufigen Revision des Systems und einem Anhang über Platyhedylidae (Opisthobranchia, Ascoglossa). PhD thesis Universität Wien; 1987.

21. Swedmark B: The biology of interstitial Mollusca. Symp Zool Soc Lond 1968, 22:135-149.

22. Schrödl M, Neusser TP: Towards a phylogeny and evolution of Acochlidia (Mollusca: Gastropoda: Opisthobranchia). Zool J Linn Soc 2010, 158:124-154.

23. Jörger KM, Heß $M$, Neusser TP, Schrödl M: Sex in the beach: spermatophores, dermal insemination and 3D sperm ultrastructure of the aphallic mesopsammic Pontohedyle milaschewitchii (Acochlidia, Opisthobranchia, Gastropoda). Mar Biol 2009, 156:1159-1170.

24. Rankin JJ: A freshwater shell-less Mollusc from the Caribbean: structure, biotics and contribution to a new understanding of the Acochlidioidea. R Ont Mus Life Sci Contrib 1979, 116:1-123.

25. Sommerfeldt N, Schrödl M: Microanatomy of Hedylopsis ballantinei, a new interstitial acochlidian gastropod from the Red Sea, and its significance for phylogeny. J Molluscan Stud 2005, 71:153-165.

26. Gosliner TM: Gastropoda: Opisthobranchia. In Microscopic Anatomy of Invertebrates, Mollusca I. Volume 5. Edited by: Harrison FW, Kohn AJ. WileyLiss, Inc:; 1994:253-355.

27. Jörger KM, Neusser TP, Haszprunar G, Schrödl M: Undersized and underestimated: 3D-visualization of the Mediterranean interstitial acochlidian gastropod Pontohedyle milaschewitchii (Kowalevsky, 1901). Org Divers Evol 2008, 8:194-214.

28. Neusser TP, Heß M, Haszprunar G, Schrödl M: Computer-based threedimensional reconstruction of the anatomy of Microhedyle remanei 
(Marcus, 1953), an interstitial acochlidian gastropod from Bermuda. J Morphol 2006, 267:231-247.

29. Neusser TP, Heß M, Schrödl M: Tiny but complex - interactive 3D visualization of the interstitial acochlidian gastropod Pseudunela cornuta (Challis, 1970). Front Zool 2009, 6:20.

30. Neusser TP, Martynov AV, Schrödl M: Heartless and primitive? 3D reconstruction of the polar acochlidian gastropod Asperspina murmanica. Acta Zool (Stockh) 2009, 90:228-245.

31. Neusser TP, Schrödl M: Tantulum elegans reloaded: a computer-based 3Dvisualization of the anatomy of a Caribbean freshwater acochlidian gastropod. Invertebr Biol 2007, 126:18-39.

32. Neusser TP, Schrödl M: Between Vanuatu tides: $3 D$ anatomical reconstruction of a new brackish water acochlidian gastropod from Espiritu Santo. Zoosystema 2009, 31:453-469.

33. Wägele H, Klussmann-Kolb A: Opisthobranchia (Mollusca, Gastropoda) more than just slimy slugs. Shell reduction and its implications on defence and foraging. Front Zool 2005, 2:1-18.

34. Vonnemann V, Schrödl M, Klussmann-Kolb A, Wägele H: Reconstruction of the phylogeny of the Opisthobranchia (Mollusca: Gastropoda) by means of $18 \mathrm{~S}$ and 28S rRNA gene sequences. J Molluscan Stud 2005, 71:113-125.

35. Swennen CK, Buatip S: Aiteng ater, new genus, new species, an amphibous and insectivorous sea slug that is difficult to classify (Mollusca: Gastropoda: Opisthobranchia: Sacoglossa(?): Aitengidae, new family). Raffles Bull Zool 2009, 57:495-500.

36. Swofford DL: PAUP* Phylogenetic analysis using parsimony (*and other methods). Sinauer Associates, Sunderland, MA; 2002.

37. Wade CM, Mordan PB: Evolution within the gastropod molluscs; using the ribosomal RNA gene-cluster as an indicator of phylogenetic relationships. J Molluscan Stud 2000, 66:565-570.

38. Dinapoli A, Zinssmeister C, Klussmann-Kolb A: New insights into the phylogeny of the Pyramidellidae (Gastropoda). J Molluscan Stud 2010.

39. Ponder WF, Avern GJ: The Glacidorbidae (Mollusca: Gastropoda: Heterobranchia) of Australia. Rec Aust Mus 2000, 52:307-353.

40. Wägele H, Klussmann-Kolb A, Vonnemann V, Medina M: Heterobranchia I: The Opisthobranchia. In Phylogeny and Evolution of the Mollusca. Edited by: Ponder WF, Lindberg D. Berkley, University of California Press; 2008:385-408.

41. Grande C, Templado J, Cervera JL, Zardoya R: Phylogenetic relationships among Opisthobranchia (Mollusca: Gastropoda) based on mitochondrial cox 1, trnV, and rrnL genes. Mol Phylogen Evol 2004, 33:378-388.

42. Göbbeler K, Klussmann-Kolb A: Phylogeny of the Acteonoidea (Gastropoda): Molecular systematics and first detailed morphological study of Rictaxis puctocaelatus (Carpenter, 1864). J Molluscan Stud 2010.

43. Ghiselin MT: Reproductive function and the phylogeny of opisthobranch gastropods. Malacologia 1966, 3:327-378.

44. Aktipis SW, Giribet G, Lindberg D, Ponder WF: Gastropoda - an overview and analysis. In Phylogeny and Evolution of the Mollusca. Edited by: Ponder WF, Lindberg D. Berkley, University of California Press; 2008:201-237.

45. Malaquias MAE, Mackenzie-Dodds J, Bouchet P, Gosliner T, Reid DG: A molecular phylogeny of the Cephalaspidea sensu lato (Gastropoda: Euthyneura): Architectibranchia redefined and Runcinacea reinstated. Zool Scr 2008, 38:23-41.

46. Tillier $S$, Masselot $M$, Tillier A: Phylogentic relationships of the pulmonate gastropods from rRNA sequences, and tempo and age of the stylommatophoran radiation. In Origin and evolutionary radiation of the Mollusca. Edited by: Taylor J. Oxford, Oxford University Press; 1996:267-284.

47. Haller B: Die Anatomie von Siphonaria gigas Less., eines opisthobranchiaten Gastropoden. Arb Zool Inst Univ Wien Zool Stat Triest 1892, 10:71-100

48. Nordsieck H: Phylogeny and system of the Pulmonata (Gastropoda). Arch Moll 1990, 121:31-52.

49. Wilson NG, Jörger KM, Schrödl M: Reducing an enigma: placing the vermiform Rhodopemorpha (Gastropoda) in a phylogeny [abstract]. Trop Nat Hist 2010, Suppl 3: 37.

50. Mordan PB, Wade CM: Heterobranchia II: The Pulmonata. In Phylogeny and evolution of the Mollusca. Edited by: Ponder WF, Lindberg DR. Berkley Los Angeles London: University California Press; 2008:409-426.

51. Ruthensteiner B: Homology of the pallial and pulmonary cavity of gastropods. J Molluscan Stud 1997, 63:353-367.

52. Marshall DJ, McQuaid CD: Relationship between heart rate and oxygen consumption in the intertidal limpets Patella granularis and Siphonaria occulus. Comp Biochem Physiol A 1992, 103:297-300.
53. Barker GM: Gastropods on land: Phylogeny, diversity and adaptive morphology. In The biology of terrestrial molluscs. Edited by: Barker GM. Oxon, New York: CAB International; 2001:1-146.

54. Ruthensteiner B: Redescription and 3D morphology of Williamia gussonii (Gastropoda : Siphonariidae). J Molluscan Stud 2006, 72:327-336.

55. Fahrner A, Haszprunar G: Microanatomy, ultrastructure, and systematic significance of the excretory system and mantle cavity of an acochlidian gastropod (Opisthobranchia). J Molluscan Stud 2002, 68:87-94.

56. Brenzinger B, Neusser TP, Glaubrecht M, Haszprunar G, Schrödl M: Redescription and 3-dimensional reconstruction of the limnic acochlidian gastropod Strubellia paradoxa (Strubell, 1892) from Ambon, Indonesia. J Nat Hist

57. Ruthensteiner B: Nervous system development of a primitive pulmonate (Mollusca: Gastropoda) and its bearing on comparative embryology of the gastropod nervous system. Boll Malacol 1998, 34:1-22.

58. Van Mol Jj: Étude morphologique et phylogénétique du ganglion cérébroide des Gastéropodes Pulmonés (Mollusques). Mém Acad Roy Belg Science 1967, 37:1-168.

59. Haszprunar $G$, Huber $G$ : On the central nervous system of Smeagolidae and Rhodopidae, two families questionably allied with the Gymnomorpha (Gastropoda, Euthyneura). J Zool 1990, 220:185-199.

60. Neusser TP, Jörger KM, Schrödl M: Exploring cerebral features in Acochlidia (Gastropoda: Opisthobranchia). Bonn Zool Beitr 2007, 55:301-310.

61. Van Mol JJ: Evolution phylogénetique du ganglion cérébroide chez les gastéropodes pulmones. Haliotis 1974, 4:77-86.

62. Tardy J: Contribution a l'étude des métamorphoses chez les nudibranches. Ann Sci Nat Zool 1970, 12:299-370.

63. Tardy J: Morphogenese du systéme nerveux chez les mollusques nudibranches. Haliotis 1974, 4:61-75.

64. Saleuddin ASM, Ashton ML, Khan HR: An electron microscopic study of the endocrine dorsal bodies in reproductively active and inactive Siphonaria pectinata (Pulmonata: Mollusca). Tissue Cell 1997, 29:267-275.

65. Ponder WF, Lindberg DR: Towards a phylogeny of gastropod molluscs: Analysis using morphological characters. Zool J Linn Soc 1997, 119:83-265.

66. Huber G: On the cerebral nervous system of marine Heterobranchia (Gastropoda). J Molluscan Stud 1993, 59:381-420.

67. Westheide W: Progenesis as a principle in meiofauna evolution. J Nat Hist 1987, 21:843-854.

68. Arnaud PM, Poizat C, Salvini-Plawen Lv: Marine-interstitial Gastropoda (including one freshwater interstitial species). In Stygofauna Mundi. Edited by: Botosaneanu L. Leiden, Brill/Backhuys; 1986:153-161.

69. Haynes A, Kenchington W: Acochlidium fijiensis sp. nov. (Gastropoda: Opisthobranchia: Acochlidiacea) from Fiji. Veliger 1991, 34:166-171.

70. Wawra E: Acochlidium sutteri nov. spec. (Gastropoda, Opisthobranchia, Acochlidiacea) von Sumba, Indonesien. Ann Naturhist Mus Wien (B Bot Zool) 1979, 82:595-604.

71. Swedmark B: The interstitial fauna of marine sand. Biol Rev 1964, 39:1-42.

72. Tillier S, Ponder WF: New species of Smeagol from Australia and New Zealand, with a discussion of the affinities of the genus (Gastropoda, Pulmonata). J Molluscan Stud 1992, 58:135-155.

73. Ho SYW, Larson G: Molecular clocks: when times are a-changin'. Trends Genet 2006, 22:79-83

74. Welch JJ, Bromham L: Molecular dating when rates vary. Trends Ecol Evol 2005, 20:320-327.

75. Arbogast BS, Edwards SV, Wakeley J, Beerli P, Slowinski JB: Estimating divergence times from molecular data on phylogenetic and population genetic timescales. Annu Rev Ecol Syst 2002, 33:707-740.

76. Wilke T, Schultheiss R, Albrecht C: As time goes by: A simple fool's guide to molecular clock approaches in invertebrates. Am Malacol Bull 2009, 27:25-45.

77. Graur D, Martin W: Reading the entrails of chickens: molecular timescales of evolution and the illusion of precision. Trends Genet 2004, 20:80-86.

78. Drummond AJ, Ho SYW, Phillips MJ, Rambaut A: Relaxed phylogenetics and dating with confidence. PLOS Biol 2006, 4:699-710.

79. Hedges SB, Kumar S: Precision of molecular time estimates. Trends Genet 2004, 20:242-247.

80. Renner SS: Relaxed molecular clocks for dating historical plant dispersal events. Trends Plant Sci 2005, 10:550-558. 
81. Malaquias MAE, Reid DG: Tethyan vicariance, relictualism and speciation: evidence from a global molecular phylogeny of the opisthobranch genus Bulla. J Biogeogr 2009, 36:1760-1777.

82. Göbbeler K, Klussmann-Kolb A: Out of Antarctica? - New insights into the phylogeny and biogeography of the Pleurobranchomorpha (Mollusca, Gastropoda). Mol Phylogenet Evol 2010, 55:996-1007.

83. Frey MA, Vermeij GJ: Molecular phylogenies and historical biogeography of a circumtropical group of gastropods (Genus: Nerita): Implications for regional diversity patterns in the marine tropics. Mol Phylogen Evol 2008, 48:1067-1086.

84. Strugnell J, Jackson J, Drummond AJ, Cooper A: Divergence time estimates for major cephalopod groups: evidence from multiple genes. Cladistics 2006, 22:89-96.

85. Bandel K, Heidelberger D: A Devonian member of the subclass Heterostropha (Gastropoda) with valvatoid shell shape. Neues Jahrb Geol Palaontol-Monatsh 2002, 533-550.

86. Bandel K: Triassic Euthyneura (Gastropoda) from St. Cassian Formation (Italian Alps) with a discussion on the evolution of the Heterostropha. Freib Forsch H C 1994, 2:79-100.

87. Bandel K, Riedel F: The Late Cretaceous gastropod fauna from Ajka (Bakony Mountains, Hungary): A revision. Ann Naturhist Mus Wien A 1994, 96:1-65.

88. Schrödl M: Techniques for collecting interstitial opisthobranchs.[http:// www.seaslugforum.net/factsheet.cfm?base=inteextr].

89. Altschul SF, Gish W, Miller W, Myers EW, Lipman DJ: Basic local alignment search tool. J Mol Biol 1990, 215:403-410.

90. Hall TA: BioEdit: a user-friendly biological sequence alignment editor and analysis program for Windows 95/98/NT. Nucleic Acids Symp Series 1999, 41:95-98.

91. Katoh K, Kuma K, Toh H, Miyata T: MAFFT version 5: improvement in accuracy of multiple sequence alignment. Nucleic Acids Res 2005, 33:511-518.

92. Talavera G, Castresana J: Improvement of phylogenies after removing divergent and ambiguously aligned blocks from protein sequence alignments. Syst Biol 2007, 56:564-577.

93. Castresana J: Selection of conserved blocks from multiple alignments for their use in phylogenetic analysis. Mol Biol Evol 2000, 17:540-552.

94. Misof B, Misof K: A Monte Carlo approach successfully identifies randomness in multiple sequence alignments: $A$ more objective means of data exclusion. Syst Biol 2009, 58:21-34.

95. Huson DH, Bryant D: Application of phylogenetic networks in evolutionary studies. Mol Biol Evol 2006, 23:254-267.

96. Posada D, Crandall KA: MODELTEST: testing the model of DNA substitution. Bioinformatics 1998, 14:817-818.

97. Farris JS, Källersjö M, Kluge AG, Bult C: Testing significance of incongruence. Cladistics 1995, 10:315-319.

98. Stamatakis A: RAxML-VI-HPC: maximum likelihood-based phylogenetic analyses with thousands of taxa and mixed models. Bioinformatics 2006 , 22:2688-2690.

99. Ronquist F, Huelsenbeck JP: MrBayes 3: Bayesian phylogenetic inference under mixed models. Bioinformatics 2003, 19:1572-1574.

100. Shimodaira $\mathrm{H}$ : An approximately unbiased test of phylogenetic tree selection. Syst Biol 2002, 51:492-508.

101. Jobb G, von Haeseler A, Strimmer K: TREEFINDER: a powerful graphical analysis environment for molecular phylogenetics. BMC Evol Biol 2004, 4:18.

102. Drummond AJ, Rambaut A: BEAST: Bayesian evolutionary analysis by sampling trees. BMC Evol Biol 2007, 7:214

103. Tracey S, Todd JA, Erwin DH: Mollusca: Gastropoda. In The fossil record. Edited by: Benton MJ. London, Chapman and Hall; 1993:131-167.

104. Hipsley CA, Himmelmann L, Metzler D, Muller J: Integration of Bayesian molecular clock methods and fossil-based soft bounds reveals early Cenozoic origin of African lacertid lizards. BMC Evol Biol 2009, 9:151.

105. Wollscheid $\mathrm{E}$, Wägele $\mathrm{H}$ : Initial results on the molecular phylogeny of the Nudibranchia (Gastropoda, Opisthobranchia) based on 18S rDNA data. Mol Phylogen Evol 1999, 13:215-226.

106. Simon C, Frati F, Beckenbach A, Crespi B, Liu H, Flook P: Evolution, weighting, and phylogenetic utility of mitochondrial gene sequences and a compliation of conserved polymerase chain reaction primers. Ann Entomol Soc Am 1994, 87:651-701.
107. Folmer O, Black M, Hoeh W, Lutz R, Vrijenhoek R: DNA primers for amplification of mitochondrial cytochrome c oxidase subunit I from diverse metazoan invertebrates. Mol Mar Biol Biotechnol 1994, 3:294-299.

doi:10.1186/1471-2148-10-323

Cite this article as: Jörger et al:: On the origin of Acochlidia and other enigmatic euthyneuran gastropods, with implications for the systematics of Heterobranchia. BMC Evolutionary Biology 2010 10:323.

\section{Submit your next manuscript to BioMed Central and take full advantage of:}

- Convenient online submission

- Thorough peer review

- No space constraints or color figure charges

- Immediate publication on acceptance

- Inclusion in PubMed, CAS, Scopus and Google Scholar

- Research which is freely available for redistribution 